\title{
The shell industry in Final Neolithic societies in Sardinia: characterizing the production and utilization of Glycymeris da Costa, 1778 valves
}

\author{
Laura MANCA \\ UMR 7269 Laboratoire méditerranéen de préhistoire Europe Afrique (LAMPEA), \\ CNRS, Université d'Aix-Marseille I, MMSH \\ 5 rue du Château de l'Horloge, F-13094 Aix-en-Provence cedex 2 (France) \\ and Università di Sassari, Dipartimento di Scienze dell'Uomo e della Formazione, \\ via Zanfarino, I-07100, Sassari (Italia) \\ and GDRI Prehistos Member http://gdreprehistos.cnrs.fr \\ laurarch78@gmail.com
}

Published on 30 December 2016

KEY WORDS

Shell industry,

use-wear traces,

Final Neolithic,

Cuccuru S'Arriu,

Sardinia.
Manca L. 2016. - The shell industry in Final Neolithic societies in Sardinia: characterizing the production and utilization of Glycymeris da Costa, 1778 valves. Anthropozoologica 51 (2) : 149-171. http://doi.org/10.5252/az2016n2a6

\section{ABSTRACT}

Analyses of the Neolithic and Chalcolithic industry in hard animal material from the western Mediterranean include a rich corpus of studies focusing on osseous industries. However, studies relating to the shell industry mainly concentrate on the production of ornamental objects, and the overall background of this raw material for the production of utensils used for transformation activities is not yet well known. The technological analysis of the hard animal industry of Cuccuru S'Arriu (Cabras, Sardinia) discovered in Final Neolithic structures (4000-3500 BC) led to the identification of many sea shells collected for making artefacts, ornamental objects and utensils. This article focuses on the morphotechnological analysis of the Glycymeris da Costa, 1778 shells used as utensils, and the identification of artefact function. In particular, the experimental activities carried out for the analysis of use-wear traces are presented. These activities enhance our understanding of artefact functions (smoothers, scrapers or small containers). Finally, this study allows us to assess the important role of this industry in the production activities of Final Neolithic societies in Sardinia and reveals previously unknown data regarding the reconstruction of the ways of life of insular prehistoric societies. It is currently one of the few Neolithic samples in the western Mediterranean. 


\begin{abstract}
RÉSUMÉ
L'industrie sur coquille dans les sociétés du Néolithique final en Sardaigne: caractérisation de la production et de l'utilisation des valves de Glycymeris da Costa, 1778.

L'analyse de l'industrie en matières dures animales du Néolithique et du Chalcolithique en Méditerranée occidentale repose sur un riche corpus d'études concernant les industries en matières osseuses. Cependant, les études relatives à l'industrie sur coquille sont le plus souvent centrées sur la production d'objets d'ornement. Le rôle que cette matière première a joué dans la production d'outils utilisés dans des activités de transformation n'est pas encore bien connu. L'analyse technologique de l'industrie en matières dures animales de Cuccuru S'Arriu (Cabras, Sardaigne) dans les structures du Néolithique final (4000-3500 av. J.-C.) a permis l'identification de nombreuses coquilles collectées dans le but de produire des objets de parure et des outils. Cet article se concentre sur l'analyse morpho-technologique de coquilles de Glycymeris da Costa, 1778 utilisées comme outils, qui a permis l'identification de la fonction des objets. Les activités expérimentales réalisées dans le cadre de l'analyse des traces d'utilisation ont permis de comprendre les fonctions de certains objets (lissoirs, grattoirs et petits conteneurs). Enfin, cette étude permet d'évaluer le rôle de cette industrie dans les activités de production des sociétés du Néolithique final en Sardaigne, révélant des informations inédites concernant la reconstruction des modes de vie des sociétés préhistoriques insulaires et représentant l'un des rares exemples pour le Néolithique de la Méditerranée occidentale.

MOTS CLÉS

Industrie sur coquille, traces d'utilisation,

Néolithique final,

Cuccuru S’Arriu Sardaigne.
\end{abstract}

\section{INTRODUCTION}

For a long time, studies of industries in hard animal materials did not systematically define the role of the shell industry in techno-economical terms in the same way as for the osseous industry. This discrepancy is due to the fact that these studies traditionally reduce shell industry analysis, together with some artefacts in other raw materials, to the production of ornamental objects. The technical, aesthetical, social and cultural aspects of this production are considered separately in terms of aims and uses. However, the techno-economical systems of shell industries in prehistoric sites must also be taken into account, not only to understand the acquisition modes, techniques and methods used during transformation, but also to reconstruct the procurement and circulation of raw materials in the studied societies. In addition to this precious information, some shell artefacts provide important data for identifying the transformation of other materials, as they can be used for different purposes, as shown by ethnographic studies (Mansur \& Clemente-Conte 2009; Attenbrow 2012; Cuenca-Solana et al. 2013) and archaeological evidence (Bernabò Brea 1946: tav. XXX, fig. 17 a-c; Vigie \& Courtin 1986; Courtin \& Vigie 1987; Vigie 1987, 1995; Gruet 1993; Taborin 2004; Choi \& Driwantoro 2007; Lammers-Keijsers 2007; Pascual Benito 2008; Manca 2010, 2013, 2014; Van Gijn \& Lammers-Keijsers 2010; Zilhão et al. 2010; Henshilwood et al. 2011; Serrand 2011; Serrand \& Vigne 2011; Gutiérrez-Zugasti \& Cuenca-Solana 2015). Besides their use as ornamental objects, shells have also been employed in the production of instruments which are often only recognizable through microscopic surface analysis.

In the past few decades, considerable progress has been made thanks to technical analysis and the analysis of use-wear traces on shells (Cristiani et al. 2005; Lucero \& Donald 2005; Choi \& Driwantoro 2007; Szabó et al. 2007; Szabó 2008;
Bonomo \& Aguirre 2009; Mansur \& Clemente-Conte 2009; Cuenca-Solana et al. 2010, 2014, 2015; Clemente-Conte \& Cuenca-Solana 2011; Douka 2011; Tumung et al. 2012, 2015; Szabò \& Koppel 2015). These studies have contributed to a more precise identification of the species used, the artefacts produced and the function and operation mode of finds, underlining the potentialities of a morpho-technofunctional approach.

Several studies carried out on the functional analysis of shells incorporated the experimental method for the establishment of a comparative reference collection.

Several species of Mediterranean bivalves were used for these experiments: Mytilus galloprovincialis (Lamarck, 1819), Ostrea edulis (Linnaeus, 1758), Ruditapes decussatus (Linnaeus, 1758), Patella Vulgata (Linnaeus, 1758) and Pecten maximus (Linnaeus, 1758) (Mansur \& Clemente-Conte 2009; CuencaSolana et al. 2010, 2013, 2015; Tumung et al. 2015). Some experiments were carried out on the Glycymeridae Glycymeris violacescens (Lamarck, 1819) (Tumung et al. 2015), with a longitudinal movement in both directions to deflesh and dislocate, for a period of ten minutes.

However, studies adopting this approach to shell industries are not systematic, and current knowledge is thus inadequate for defining their role in prehistoric societies in the western Mediterranean. For the present analysis of the Final Neolithic shell industry (4000-3500 BC) from Cuccuru S'Arriu (Cabras, Oristano, Italy), the experimental method played a central role. The discovery of Glycymeridae valves with clear non-human modifications caused by abrasion on beaches or undertows (Bignon et al. 2008; Manca 2011, 2013) before they were transported to the site demonstrated the deliberate introduction of the remains to the site for non-food purposes. We then sought to confirm the anthropogenic action on these valves. This involved the observation of the remains from two distinct and complementary viewpoints. The technical 
perspective aimed to identify the marks associated with the transformation of the raw material, while the use-wear perspective focused on identifying traces of use.

\section{ARCHAEOLOGICAL CONTEXT}

The site of Cuccuru S'Arriu is at a strategic location between the inland waters and external waters, on the south-western shores of Cabras pond on a fossil barrier beach, near the coastline overlooking the Gulf of Oristano (Sardinia, Italy). The site was discovered in the late 18th century by Zanardelli (Zanardelli 1899: 161; Santoni 1977) and later studied by Atzeni (Atzeni 1962: 192; 1975; 1978: 83), then excavated under the direction of V. Santoni during the 1970s and 1980s (Santoni 1989). The excavation comprised an area of about 3750 square meters, which only represents part of the archaeological complex.

Various Neolithic and Chalcolithic phases were identified at the site of Cuccuru S'Arriu, which correspond to distinct cultural contexts: the necropolis and habitat of the Middle Neolithic Bonu Ighinu (4800-4400 BC) and the habitat structures ("fondi di capanna" and refuse pits) of San Ciriaco (4400-4200/4000 BC), Ozieri I (4200-3700 BC) and Ozieri II or sub-Ozieri (3500-2900 BC) (Santoni 1982a: 70). Absolute dating indicates Middle Neolithic occupation phases (structure 422 (bone; AMS dates): AA-58900: cal. 2 sigma 4685-4437; AA-58901: cal. 2 sigma 4590-4340; AA-58902: cal. 2 sigma 4790-4500; AA-75644: cal. 2 sigma 4778-4494) (Bignon et al. 2008: 774; Sebis et al. 2012: 500). No comprehensive study of the abundant remains found at the site has yet been published. However, the study of the significant material remains, especially ceramics and the lithic industry, helped to identify and characterize other phases (Santoni 1989, 1991, 1992, 1999; Santoni et al. 1997).

This research focused on part of the habitat site, comprising burial structures with archaeological levels in Area C, which yielded remains chronologically attributed to Ozieri I. During a first phase of research, we selected the pieces potentially belonging to the shell industry from the (still unpublished) faunal remains. Most of the shell industry is represented by bivalves (81 specimens) and only occasionally by gastropods (5 specimens) (Table 1). The most common shell type in the corpus is the Glycymeris from the Ozieri I structures located in sector $\mathrm{C}$ (structures 126 bis, 129, 131, 132, 133 bis, 147, 164, 165, 172, 173, 173 ter, 175, 175 bis, 179) (Santoni 1982b, 1989). The chronological attribution to Ozieri I is based on a bibliographic overview, the consultation of the planimetric and excavation data and the precious support of Vicenzo Santoni.

\section{MATERIALS AND METHODS}

The studied corpus includes 65 Glycymeridae valves. Among them we identified 43 Glycymeris glycymeris (Linnaeus, 1758) and Glycymeris pilosa (Linnaeus, 1767) samples, 13 Glycymeris sp. specimens and nine Glycymeris nummaria (Linnaeus, 1758) specimens (Table 1).
TABLE 1. - Composition of the hard animal shell industry from the Ozieri I phase of Cuccuru S'Arriu site ( $\mathrm{C}$ sector structures). Abbreviation: NR, number of remains.

\begin{tabular}{|c|c|c|c|}
\hline Famille & Espèce & NR & $\%$ \\
\hline Gastéropodes & & 5 & 5,81 \\
\hline Cerithiidae (Fleming, 1822) & $\begin{array}{l}\text { Cerithium cf. vulgatum } \\
\text { (Bruguière, 1792) }\end{array}$ & 3 & 3,49 \\
\hline $\begin{array}{l}\text { Muricidae (Rafinesque, } \\
\text { 1815) }\end{array}$ & $\begin{array}{l}\text { Hexaplex trunculus } \\
\text { (Linnaeus, } 1758 \text { ) }\end{array}$ & 1 & 1,16 \\
\hline $\begin{array}{l}\text { Muricidae (Rafinesque, } \\
\text { 1815) }\end{array}$ & $\begin{array}{l}\text { Stramonita haemastoma } \\
\text { (Linnaeus, 1767) }\end{array}$ & 1 & 1,16 \\
\hline Bivalves & & 81 & 94,19 \\
\hline $\begin{array}{l}\text { Glycymerididae (Dall, } 1908 \\
(1847)\end{array}$ & $\begin{array}{l}\text { Glycymeris glycymeris/ } \\
\text { pilosa (Linnaeus, 1758) }\end{array}$ & 43 & 50,00 \\
\hline $\begin{array}{l}\text { Glycymerididae (Dall, } 1908 \\
\text { (1847) }\end{array}$ & Glycymeris sp. & 13 & 15,12 \\
\hline $\begin{array}{l}\text { Glycymerididae (Dall, } 1908 \\
\text { (1847) }\end{array}$ & $\begin{array}{l}\text { Glycymeris nummaria } \\
\text { (Linnaeus, 1758) }\end{array}$ & 9 & 10,47 \\
\hline Spondylidae (Gray, 1826) & $\begin{array}{l}\text { Spondylus gaederopus } \\
\text { (Linnaeus, 1758) }\end{array}$ & 8 & 9,30 \\
\hline Spondylidae (Gray, 1826) & $\begin{array}{l}\text { Spondylus cf. } \\
\text { crassicosta }\end{array}$ & 2 & 2,33 \\
\hline $\begin{array}{l}\text { Ostreidae (Rafinesque, } \\
\text { 1815) }\end{array}$ & $\begin{array}{l}\text { Ostrea edulis (Linnaeus, } \\
\text { 1758) }\end{array}$ & 1 & 1,16 \\
\hline Cardiidae (Lamarck, 1809) & $\begin{array}{l}\text { Cerastoderma glaucum/ } \\
\text { edule }\end{array}$ & 1 & 1,16 \\
\hline Cardiidae (Lamarck, 1809) & $\begin{array}{l}\text { Acanthocardia } \\
\text { tuberculata (Linnaeus, } \\
\text { 1758) }\end{array}$ & 1 & 1,16 \\
\hline $\begin{array}{l}\text { Veneridae (Rafinesque, } \\
\text { 1815) }\end{array}$ & $\begin{array}{l}\text { cf. Venerupis decussata } \\
\text { (Linnaeus, 1758) }\end{array}$ & 1 & 1,16 \\
\hline Bivalvia & Bivalvia & 2 & 2,33 \\
\hline TOTAL & & 86 & 100,00 \\
\hline
\end{tabular}

For the analysis of this collection we followed the experimental protocol, which consists in the transformation of various raw materials of animal, plant and mineral origin. The valves used in the experiments were collected dead on the beaches near the Cuccuru S'Arriu site (near the archaeological site of Tharros West and San Giovanni di Sinis) (Fig. 1) in order to study the macroscopic characteristics of the valves found at the Cuccuru S'Arriu site (see below, paragraph "Characterisation of the natural surfaces"). We recorded the microscopic characteristics of twelve of these shells before their modification through experimentation as a benchmark for distinguishing microtraces of natural origin from anthropogenic traces.

We then characterized the macro and microtraces present on the surfaces in order to identify their function (action) and functioning (mode of action). The description of micro use-wear traces is based on two different types of traces: micro-polish and striations (Plisson 1985; Peltier \& Plisson 1986; Maigrot 1993, 2003; Christidou 1999; Legrand 2005; Mansur et al. 2014; Bradfield 2015; Evora 2015). The main micro-polish traces, and their characterization (location, position, organization, micro-topography, microrelief, texture, fabric, contouring, extension, and brightness), define the mode of use and the hardness of the worked material. In the same way, the characterization of striations (location, position, organization, orientation, frequency, continuity, morphology and dimensions) indicates the direction of movement during use. 


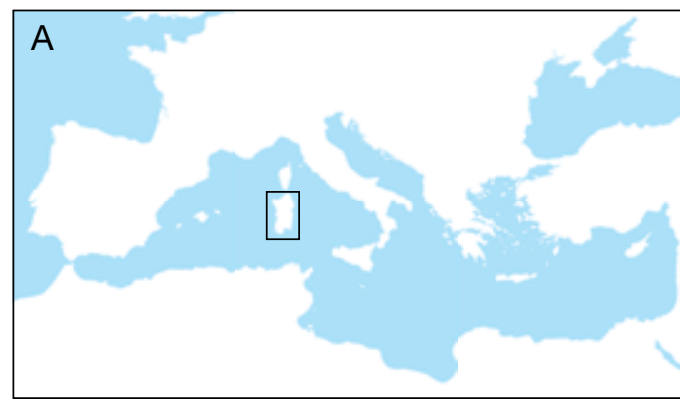

B

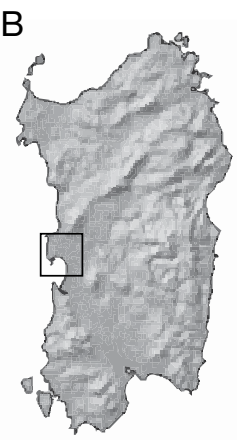

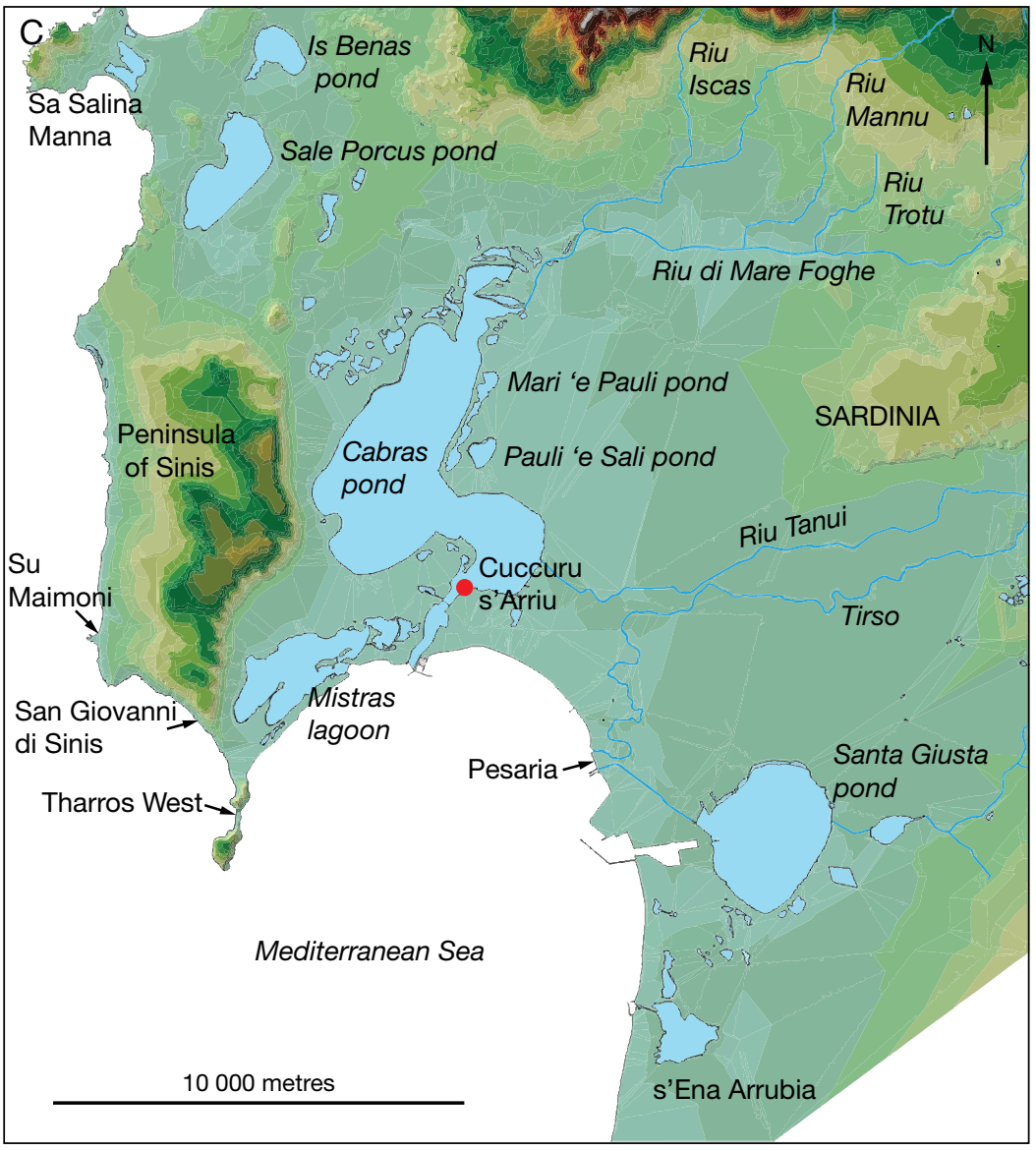

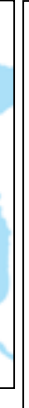

Altitude $(\mathrm{m})$

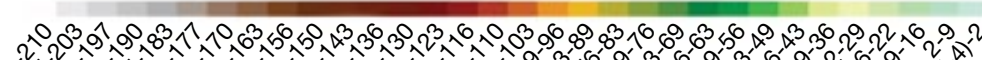

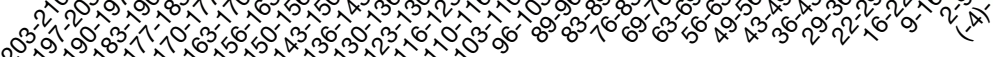

FIG. 1. - A, B, Geographical data; C, Location of the site of Cuccuru s'Arriu (red point) and indication of beaches near the site with Glycymeris valves (Tharros West, San Giovanni di Sinis, Su Maimoni and Pesaria).

All the experimental and archaeological shells were observed using an Olympus stereomicroscope (×3.8-×40 magnification), and photographs of the macroscopic traces were taken with a Canon EOS 550D camera ( $\times 5.7-\times 80$ magnification). A Leica MDR metallographic microscope (lenses $\times 50, \times 100, \times 200$, $\times 500$ ) was used for higher magnifications with the Canon $550 \mathrm{D}$ camera. For greater depth of field, we systematically took several photos of the same area focusing the lens on a different part of the object for each shot. The Helicon Focus program was then used to blend all the sharp areas together and produce a completely sharp image. This procedure is often used by archaeologists (Plisson 1997: 378, 379), and was applied to our photomicrographs and photomacrographs whenever necessary.

All experimental and archaeological use-wear traces are visible and can be characterized at magnifications of $\times 100$ and $\times 200$, but the observation of bright surfaces is often difficult, and sometimes raises problems for identifying striations and evaluating the brightness of the polish. Better contrast facilitates the observation of the surfaces, and can be obtained with the use of differential interferential contrast (Plisson \& Lompré 2008).

\section{EXPERIMENTATIONS}

The shell valves used for the experiments are Glycymeridae and were collected on the beaches near the site of Cuccuru s'Arriu (Fig. 2A), apart from four Tapes decussatus (Linnaeus, 1758) valves used for a long time ( 1 consecutive month) for smoothing and scraping clay. They were included in our experimental corpus on account of the long period of use.

The Glycymeridae valves bear clear traces of natural modifications, identical to those present on most of the archaeological remains. These modifications were described and characterized on the experimental valves before the experiments.

\section{CHARACTERIZATION OF THE NATURAL SURFACES}

The macroscopic observation of surfaces made it possible to confirm the natural modifications previously described by several authors (Driscoll \& Weltin 1973; Parsons \& Brett 1991) (Fig. 2B): rounded valve edges, the presence of a hole in the umbo with convex margins, impact traces evidenced by the absence of certain parts of the valve, rounded fractured edges, or by still visible fracture lines, 


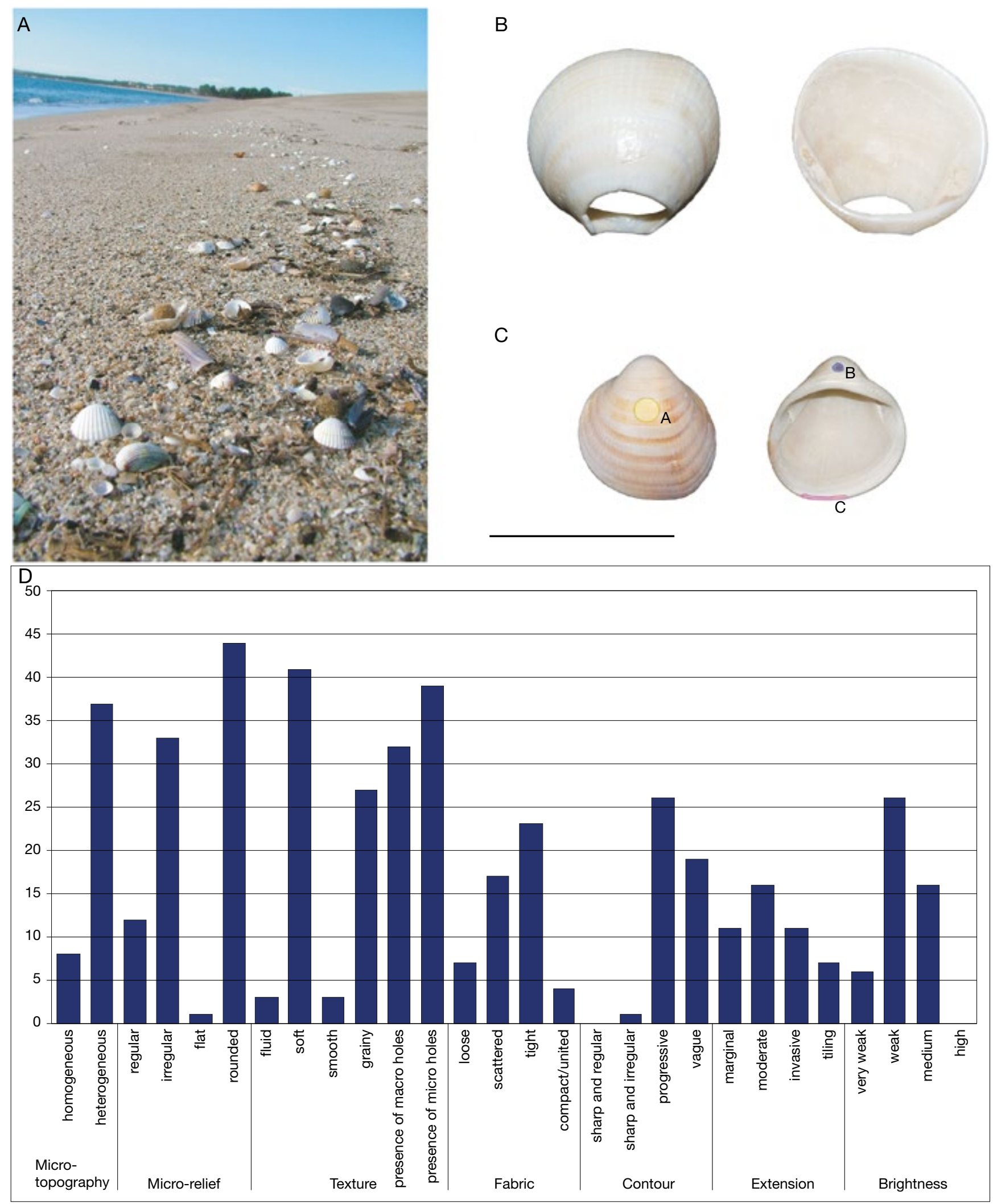

FIG. 2. - A, area of experimental shell collection; B, macroscopic evidence of non-human modifications on experimental Glycymeris valves; C, localization of points with abundant natural microtraces; $\mathbf{D}$, frequency distribution of the characteristics of natural micro-polishes. Scale bar: $5 \mathrm{~cm}$.

a glossy surface, and in certain cases the presence of an opaque white patina caused by the exposure of the valves to atmospheric conditions.
Although the whole surface was analysed, the photographic and descriptive record of the microtraces focused mainly on the zones that normally reveal the presence of human use- 

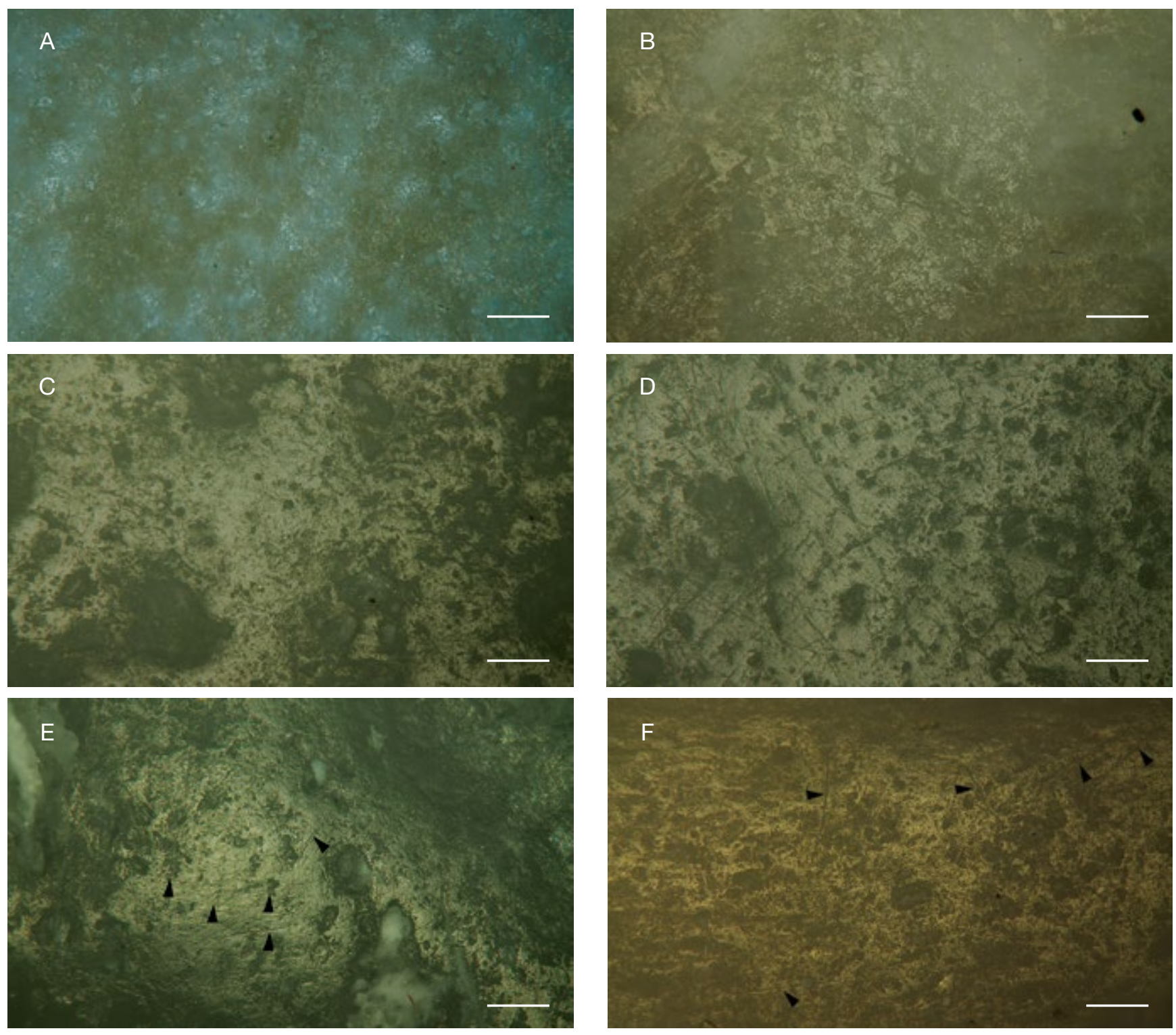

FIG. 3. - A-D, micro-polishes identified on the dorsal face of Glycymeris valves with different microtopography, texture, fabric and extension: A, absence of micropolish; B-D, presence of micro-polish becoming gradually more marked; $\mathbf{E}, \mathbf{F}$, scratches identified on the dorsal face of valves. Scale bars: $100 \mu \mathrm{m}$.

wear traces, like the umbo, for the suspension or binding of the valves, or like the edge and the ventral face, for the use of valves as tools (Fig. 2C). Out of the 12 observed valves, 50 zones were described and photographed and 45 microtraces were identified.

The majority of the microtraces of natural origin on the valves are micro-polishes. They are concentrated in the zones most exposed to the erosive action of the tide and the beach, like the edges, the umbo and the dorsal face. They are mainly micro-polishes with a heterogeneous micro-topography, irregular and rounded microrelief, distributed in a linear way compared to the examined zone, with a mainly tight but scattered fabric, a grainy texture with the frequent presence of macro and micro-holes. The contour is only seldom sharp; it often has a progressive aspect and, in many cases, remains fuzzy. The brightness ranges from weak to medium and can be extremely variable (Figs 2D, 3A-D).

Unlike micro-polishes, scratches were not frequently observed: out of 45 zones with identified microtraces, we only recorded the presence of scratches in 15 cases. They are located mainly on the umbo (8 cases), on the dorsal face (6 cases) and only in one case on the edges.

The scratches are mainly narrow and superficial, of variable length, of low density and random orientation, although there are cases where they are dispersed obliquely in relation to the longitudinal axis of the valve. They are either organized, parallel or subparallel or intersecting each other, or distributed in a random way (Fig. 3E, F). Two characteristics can be taken into consideration for 
TABLE 2. - Description of the experimental sample and experimental activities.

\begin{tabular}{|c|c|c|c|c|c|c|c|}
\hline $\begin{array}{l}\text { Number of } \\
\text { valves }\end{array}$ & Activity & $\begin{array}{l}\text { Direction of movement } \\
\text { in relation to the active } \\
\text { part of valve }\end{array}$ & \multicolumn{3}{|c|}{$\begin{array}{l}\text { Inclination of tool in relation } \\
\text { to the worked surface }\end{array}$} & $\begin{array}{l}\text { Surfaces of block in } \\
\text { contact with worked } \\
\text { material }\end{array}$ & Worked material \\
\hline 2 & scraping & transverse bidirectional & \multicolumn{4}{|c|}{$\begin{array}{l}\text { oblique }\left(45^{\circ}\right) \text { towards dorsal face / edge } \\
\text { perpendicular }\left(90^{\circ}\right)\end{array}$} & goat skin \\
\hline 2 & $\begin{array}{l}\text { scraping } \\
\text { (softening) }\end{array}$ & transverse bidirectional & \multicolumn{3}{|c|}{ oblique $\left(135^{\circ}-45^{\circ}\right)$} & edge & $\begin{array}{l}\text { tanned and rigid } \\
\text { sheepskin }\end{array}$ \\
\hline 1 & scraping & transverse bidirectional & \multicolumn{3}{|c|}{ perpendicular $\left(90^{\circ}\right)$} & edge & tanned lambskin \\
\hline 2 & scraping & transverse bidirectional & \multicolumn{3}{|c|}{ perpendicular $\left(90^{\circ}\right)$} & edge & tanned wild boar skin \\
\hline 2 & scraping & transverse bidirectional & \multicolumn{4}{|c|}{$\begin{array}{l}\text { oblique }\left(45^{\circ}\right) \text { towards dorsal face / edge } \\
\text { perpendicular }\left(90^{\circ}\right)\end{array}$} & tanned wild boar skin \\
\hline 2 & scraping & transverse bidirectional & \multicolumn{3}{|c|}{ grazing angle } & edge & tanned sheep skin \\
\hline 2 & scraping & transverse bidirectional & \multicolumn{3}{|c|}{ oblique $\left(30^{\circ}-70^{\circ}\right)$} & edge & wood of boxwood \\
\hline 2 & scraping & transverse bidirectional & \multicolumn{3}{|c|}{ oblique $\left(30^{\circ}-70^{\circ}\right)$} & edge & bark of basswood \\
\hline 2 & scraping & transverse bidirectional & \multicolumn{3}{|c|}{ perpendicular $\left(90^{\circ}\right)$} & edge & Juncus acutus \\
\hline 2 & scraping & transverse bidirectional & \multicolumn{3}{|c|}{ perpendicular $\left(90^{\circ}\right)$ /oblique $\left(100^{\circ}\right)$} & edge / dorsal face & Linum cf. usitatissimum \\
\hline 2 & polishing & oblique & \multicolumn{3}{|c|}{ grazing angle } & dorsal face & clay \\
\hline$\overline{1}$ & smoothing & perpendicular & \multicolumn{3}{|c|}{ grazing angle } & edge & clay \\
\hline 1 & $\begin{array}{l}\text { smoothing/ } \\
\text { scraping }\end{array}$ & perpendicular & \multicolumn{3}{|c|}{ abrupt $\left(80^{\circ}\right)$} & edge & clay \\
\hline $\begin{array}{l}4 \text { (Tapes } \\
\text { decussatus) }\end{array}$ & smoothing/ & pluridirectional & \multicolumn{3}{|c|}{ grazing angle } & dorsal face & clay \\
\hline 2 & friction & rotating movement & \multicolumn{3}{|c|}{$\begin{array}{l}\text { perpendicular }\left(90^{\circ}\right) \text {; abrupt }\left(80^{\circ}\right) \\
\quad \text { oblique }\left(45^{\circ}\right)\end{array}$} & ventral face and edges & $\begin{array}{l}\text { ochre+egg white } \\
\text { +fingers }\end{array}$ \\
\hline 2 & friction & rotating movement & \multicolumn{3}{|c|}{$\begin{array}{l}\text { perpendicular }\left(90^{\circ}\right) \text {; abrupt }\left(80^{\circ}\right) \text {; } \\
\text { oblique }\left(45^{\circ}\right)\end{array}$} & ventral face and edges & $\begin{array}{l}\text { ochre+egg white + hairs } \\
\text { of wild boar }\end{array}$ \\
\hline $\begin{array}{l}\text { Number of } \\
\text { valves }\end{array}$ & Activity & State of raw material & \multicolumn{2}{|c|}{$\begin{array}{l}\text { Time of working/ } \\
\text { minutes }\end{array}$} & \multicolumn{2}{|c|}{ Observations / figures } & \\
\hline 2 & scraping & wet & 5 & 15 & \multicolumn{3}{|c|}{$\begin{array}{l}\text { The working of wet skin is not illustrated in the paper due to the } \\
\text { inefficacy of this technical action. }\end{array}$} \\
\hline 2 & $\begin{array}{l}\text { scraping } \\
\text { (softening) }\end{array}$ & dry & 5 & 15 & \multicolumn{2}{|c|}{ Figs $4 \mathrm{~A} ; 4 \mathrm{~B}$} & \\
\hline 2 & scraping & dry & 5 & 15 & \multicolumn{2}{|c|}{ Figs 4C; 4D; 4E; 4F } & \\
\hline 2 & scraping & dry & 5 & 15 & \multicolumn{3}{|c|}{$\begin{array}{l}\text { These use-wear traces are similar to those obtained with tanned } \\
\text { lambskin. }\end{array}$} \\
\hline 2 & scraping & re-wet & 5 & 15 & / & & \\
\hline 2 & scraping & dry + ochre & 5 & 15 & Figs $5 \mathrm{~A} ; 5 \mathrm{~B} ; 5$ & $\mathrm{C} ; 5 \mathrm{D}$ & \\
\hline 2 & scraping & dry & 5 & 15 & Figs $5 \mathrm{E} ; 5 \mathrm{~F}$ & & \\
\hline 2 & scraping & wet & 5 & 15 & Figs 5G; $5 \mathrm{H}$ & & \\
\hline 2 & scraping & $\begin{array}{l}\text { worked } 2 \text { weeks after } \\
\text { the collecting }\end{array}$ & 5 & 15 & Figs $6 \mathrm{~A} ; 6 \mathrm{~B} ; 6$ & $C ; 6 \mathrm{D}$ & \\
\hline 2 & scraping & dry & 5 & 15 & Figs 6E; 6F; 6C & $\mathrm{G} ; 6 \mathrm{H}$ & \\
\hline 2 & scraping & dry & 5 & 15 & These use-we & ar traces are similar to the & ose obtained with flax. \\
\hline 2 & polishing & wet & 5 & 15 & $\begin{array}{l}\text { (clay with addi } \\
\text { Fig. } 7 \mathrm{~A}, \mathrm{~B}\end{array}$ & ition of calcareous inclusic & ions $-\geq 1 \mathrm{~mm}$ ) \\
\hline 1 & smoothing & wet & 15 & & / & & \\
\hline 1 & $\begin{array}{l}\text { smoothing/ } \\
\text { scraping }\end{array}$ & wet & 15 & & $\begin{array}{l}\text { (clay with addi } \\
\text { Fig. 7C; 7D }\end{array}$ & ition of calcareous inclusic & ions $-\leq 1 \mathrm{~mm})$ \\
\hline $\begin{array}{l}4 \text { (Tapes } \\
\text { decussatus) }\end{array}$ & $\begin{array}{l}\text { smoothing/ } \\
\text { scraping }\end{array}$ & wet & month & & Figs 7E-G & & \\
\hline 2 & friction & wet & 30 & 60 & (granulometry & of grains: $3<x<1 \mathrm{~mm}$ ) & Figs $8 \mathrm{~A}, \mathrm{~B}$ \\
\hline 2 & friction & wet & 30 & 60 & $\begin{array}{l}\text { This experime } \\
\text { use-wear tre }\end{array}$ & $\begin{array}{l}\text { ntation is not illustrated in } \\
\text { aces }\end{array}$ & $\mathrm{n}$ the paper as it left no \\
\hline
\end{tabular}

a comparison between the microtraces of natural origin and those of anthropogenic origin: the low density and shallow depth of the scratches. These characteristics are present in almost all the cases and the only exceptions are strictly related to location of use-wear traces: the presence of dense scratches and variable depths were only identified on the dorsal face.

\section{MICROSCOPIC CHARACTERIZATION OF EXPERIMENTAL} USE-WEAR TRACES

The activities carried out in the experiments with the valves were based on ethno-archaeological examples, in keeping with evidence of the potential activities at the archaeological site (Leroi-Gourhan 1945), indicating the potentially worked materials and methods of use. The experimental tests related to 
production activities ( 35 valves) (Table 2 ). In order to estimate the time necessary for the formation of surface modifications, we carried out experiments with durations of 5 minutes and 15 minutes. The latter duration results in the formation of a more marked polish with well-developed scratches, which we will describe below.

\section{Animal matter, skin in a dry state}

Softening skin to the very fine hypodermis does not require very much work. Once dry, the skin can be cleaned of possible residues and softened at the same time (Beyries 2008: 23). This activity is usually conducted with a pebble, but due to the robustness and the morphology of the edges of Glycymeridae valves, we tested the effectiveness of these shells. Pieces of dry lambskin were placed on a wooden anvil and scraped with a bidirectional transverse movement. The contact angle between the edge of the valve and the skin was almost perpendicular. The micro-polish on the edge after 15 minutes is flat, with a regular micro-topography and a flat microrelief, compact fabric and a smooth texture. The contour is progressive, the brightness is remarkable and the extension is invasive (Fig. 4A, B). The scratches are long, and of variable width and depth. They are dense and parallel to each other.

Before being used, skin can be treated in order to thin it, to regularize any possible asperities and to make it more supple. It can also be coloured by scraping associated with colouring substances. In order to reproduce these operations, the dry sheepskin was scraped, on the one hand without the addition of abrasive substances, and on the other, by adding ochre. The skin was placed on a wooden anvil. The movement of the valve was transverse and bidirectional. The edge of the valves were at an oblique angle $\left(45^{\circ}\right.$ and $\left.135^{\circ}\right)$ for scraping without ochre (Fig. 4C, D), whereas for colouring the skin with ochre the dorsal face of the valves was used at a very slight angle (Fig. 5A, B).

The traces obtained by scraping without abrasive substances are micro-polishes and scratches.

The micro-topography on the edge is homogeneous with a regular rounded microrelief. It appears a dense fabric and a smooth and soft texture. The contour is sharp and irregular, it is invasive and very bright (Fig. 4E, F). The irregular contour of the polished surface follows the direction of the movement: small extensions stem out from the "body" of the polish with a perpendicular orientation in relation to the edge of the shell. The scratches are short, fine and not very deep, dense and parallel to each other.

The traces produced by scraping the skin with ochre as a colouring substance are more marked.

The micro-polish developed on the dorsal face is localized in a semicircular linear zone. The micro-topography is homogeneous and the microrelief is irregular with a tight fabric and a grainy texture. The contour is regular, of medium brightness and polish extension is relatively invasive (Fig. 5C, D). The surface is characterized by macro-holes with irregular contours. The scratches are long, of variable depth and width, dense and subparallel. We also distinguish curved scratches.

\section{Plant matter, wood}

The use of shell valves for working wood is attested in several populations (Cuenca-Solana et al. 2011: 84). We tested scraping (on boxwood) and hulling basswood fibres. The edge of the valves was used in a transverse direction, at an angle oscillating between $70^{\circ}$ and $30^{\circ}$.

Scraping wood for 15 minutes resulted in the formation of polish and scratches (Fig. 5E, F). The polish is localized along the edge and extends slightly onto the lower face. The microtopography is homogeneous and the microrelief is regular and rounded, with a tightened fabric and a soft flat texture. It is of marginal extension and with a progressive contour, with macro-holes and micro-holes. The brightness is marked in the central part and moderate towards the periphery of the polish. Scratches accompany the whole extension of the polish; they are dense, short and discontinuous, fine and superficial.

The traces related to scraping the interior of the basswood bark are slightly different from those previously described (Fig. 5G, H). The polish is localized along the edge and extends slightly onto the lower face. The micro-topography is heterogeneous and the microrelief is irregular and rounded, with marginal extension, a progressive contour, a joined fabric and smooth texture, and macro-holes and micro-holes. The brightness is marked. Scratches accompany the whole extension of the polish; they are of medium density and are short and discontinuous, fine and superficial.

\section{Plant matter, rushes}

This material (Juncus acutus L.) was probably used by the population of Cuccuru s'Arriu. Rushes are very abundant in marshy environments and can be used for clothes, cords and baskets. The separation of the stems is traditionally carried out with knives or awls, but scraping can easily be carried out with shell valves. Once the edge of the valve is inserted in the cut end of the stem, simple pressure and a longitudinal movement make it possible to divide it over its entire length. This operation also eliminates the internal woody part (Fig. 6A, B)

We observe the formation of use-wear traces on the edge with an extension limited to several millimetres. The microtopography is homogeneous and the microrelief is regular and rounded, with a tightened fabric and a soft grainy texture, with macro-holes. The contour is progressive, the brightness is strong and the extension is marginal (Fig. 6C, D). The scratches are loose, short, fine and continuous, parallel to each other and oriented transversely in relation to the cutting edge. Their density changes when the shells are used for a longer duration.

\section{Plant matter, flax}

We used the edge of the valves to crush the woody part to prepare the flax for obtaining fibres. This activity is traditionally carried out by hammering fibres on a flat stone or by placing the dry flax between two planks of wood (Médard 2006: 41). We positioned the flax stems (linum cf. usitatissimum) on a wooden anvil and crushed them with a bidirectional movement of the valve. The edge of the valve was used at a perpendicular $\left(90^{\circ}\right)$ and more open 

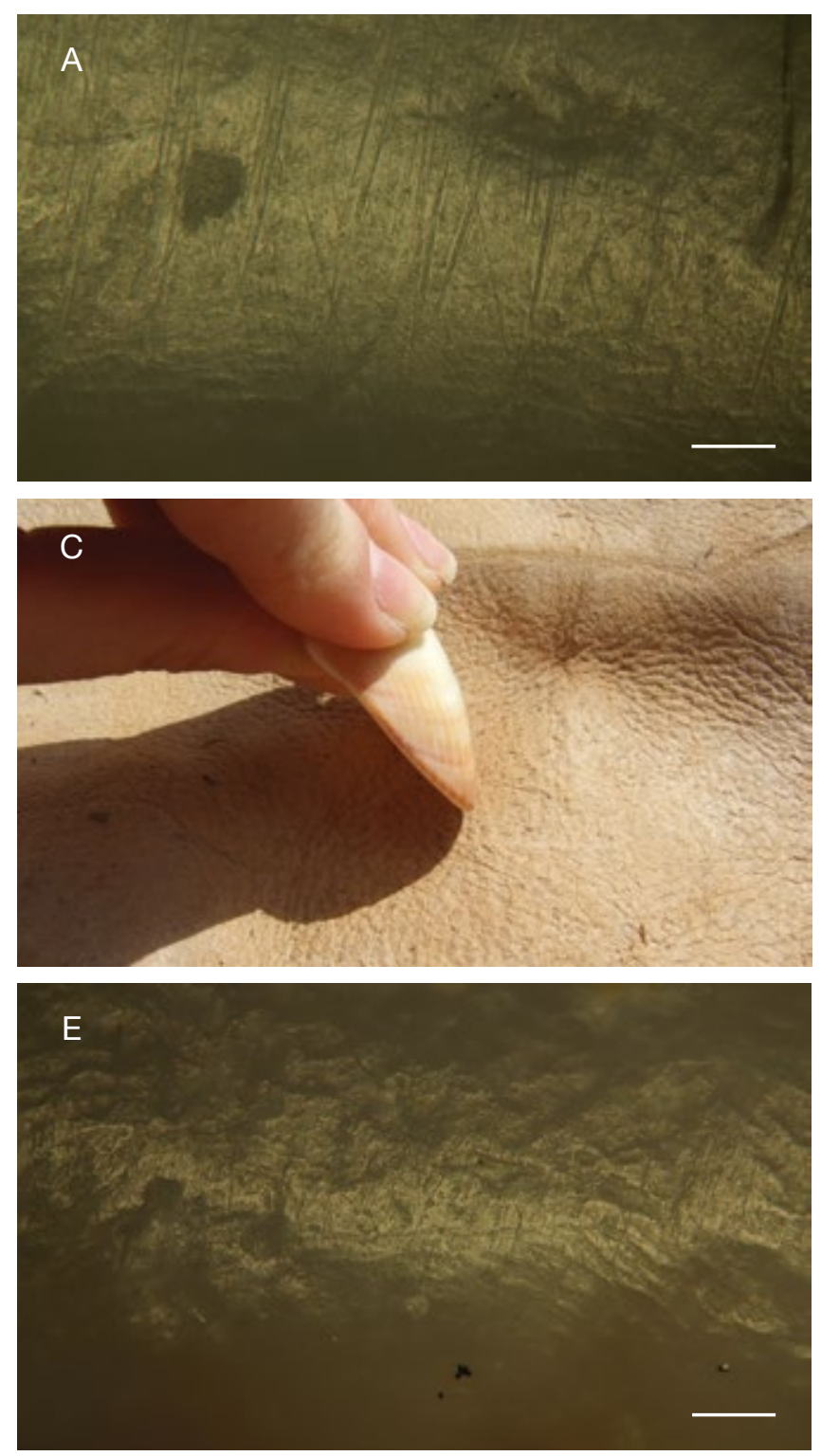
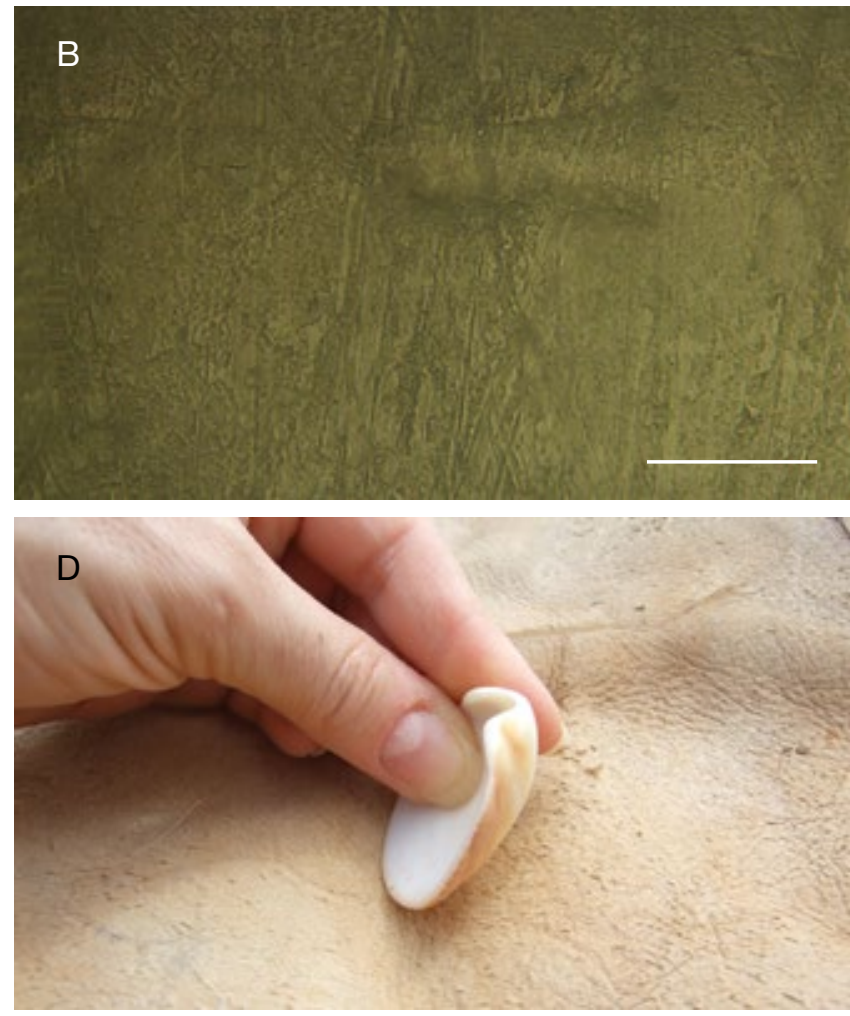

$\mathrm{F}$

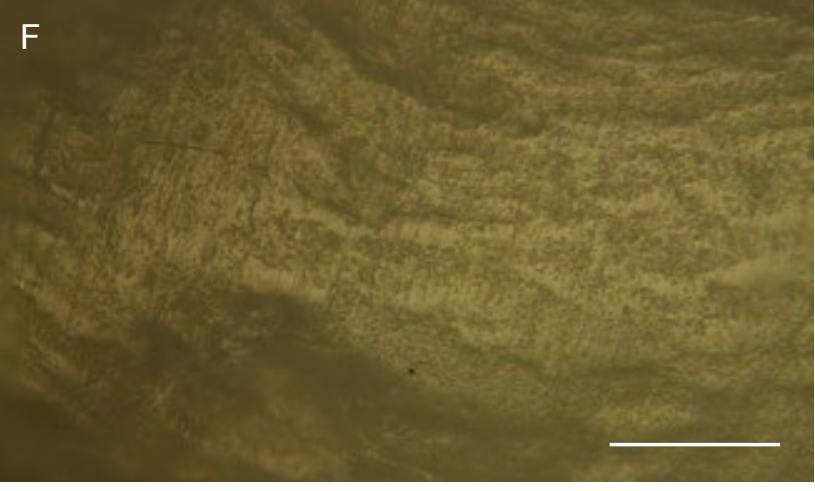

FIG. 4. - A, B, experimental shell surface used to process dry hide (softening; 15 minutes); C, D, working conditions (C, $45^{\circ}$ inclination; D, $135^{\circ}$ inclination); E, F, experimental shell surface used to process dry hide (scraping). Scale bars: $100 \mu \mathrm{m}$.

$\left(100^{\circ}\right)$ angle (Fig. 6E). The active part, with a convex section and non-cutting edge, enabled us to crush the woody parts of a modest amount of flax without damaging the fibres (Fig. 6F).

The polish that developed after 15 minutes maintains a homogeneous micro-topography and a regular rounded microrelief with a tightened or compact fabric (Fig. 6G, H). The texture is soft and flat. The macro- and micro-holes become more marked and numerous. The striations are located on the upper (dorsal) edge, indicating an open active angle. The striations are dense, long, thin and continuous and parallel to each other.

\section{Mineral matter, clay}

Various ethnographic examples confirm the use of shell valves to smooth ceramics. This use has been documented in the Canary Islands (Rodríguez \& Navarro 1999) and in several African populations (Dupont 2003; Cuenca-Solana et al. 2011).

The use of the dorsal face held at an acute angle makes it possible to obtain a polish with a compact fabric (Fig. 7A, B).

The valve fragment used to smooth wet clay during the assembly phase presents very few microtraces (Fig. 7C, D). The micro-polish only affects the most marked parts of the structural composition of the valve.

The traces on the valves used for approximately one month present different macro-characteristics depending on their localization on the valve. The micro-topography on the dorsal face is homogeneous with a regular flat microrelief and has a compact fabric and a smooth texture. It is characterized by a progressive contour, strong brightness and is relatively invasive (Fig. 7E). The scratches are long, fine and not very deep, dense and parallel to each other. 

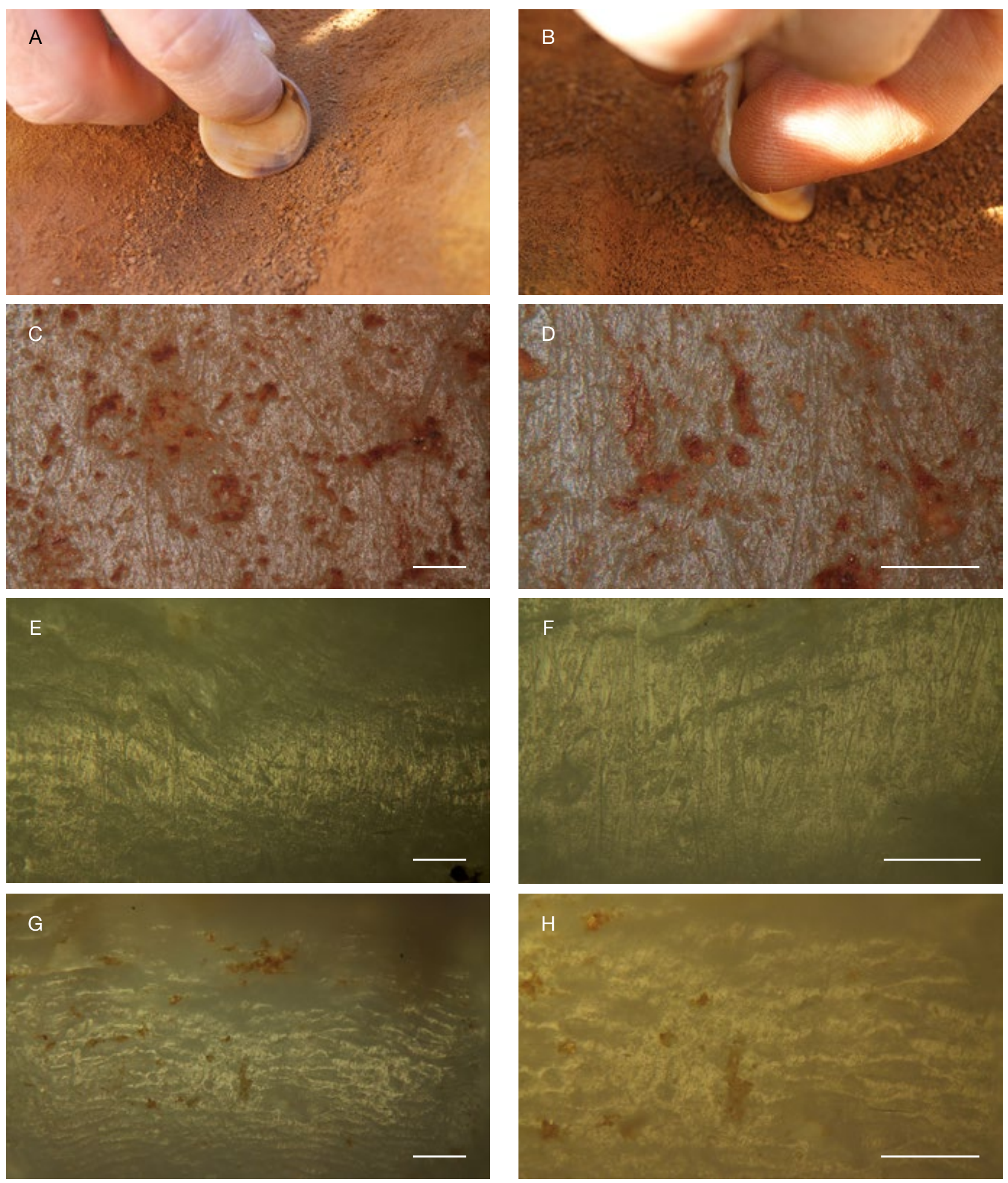

FIG. 5. - A, B, working conditions (A, $45^{\circ}$ inclination; B, $135^{\circ}$ inclination); C, D, experimental shell surface used to process dry hide (scraping with the use of ochre; 15 minutes); E, F, experimental shell surface used to process boxwood (scraping; 15 minutes); $\mathbf{G}, \mathbf{H}$, experimental shell surface used to process basswood (scraping; 15 minutes). Scale bars: $100 \mu \mathrm{m}$.

On the dorsal face near the edges (Fig. 7F), the microtopography is homogeneous with a regular rounded microrelief and with a scattered fabric and soft texture. The contour is progressive with medium brightness, and it is relatively invasive. The scratches have the same characteristics as those previously described. The cutting edge of the higher edge of 

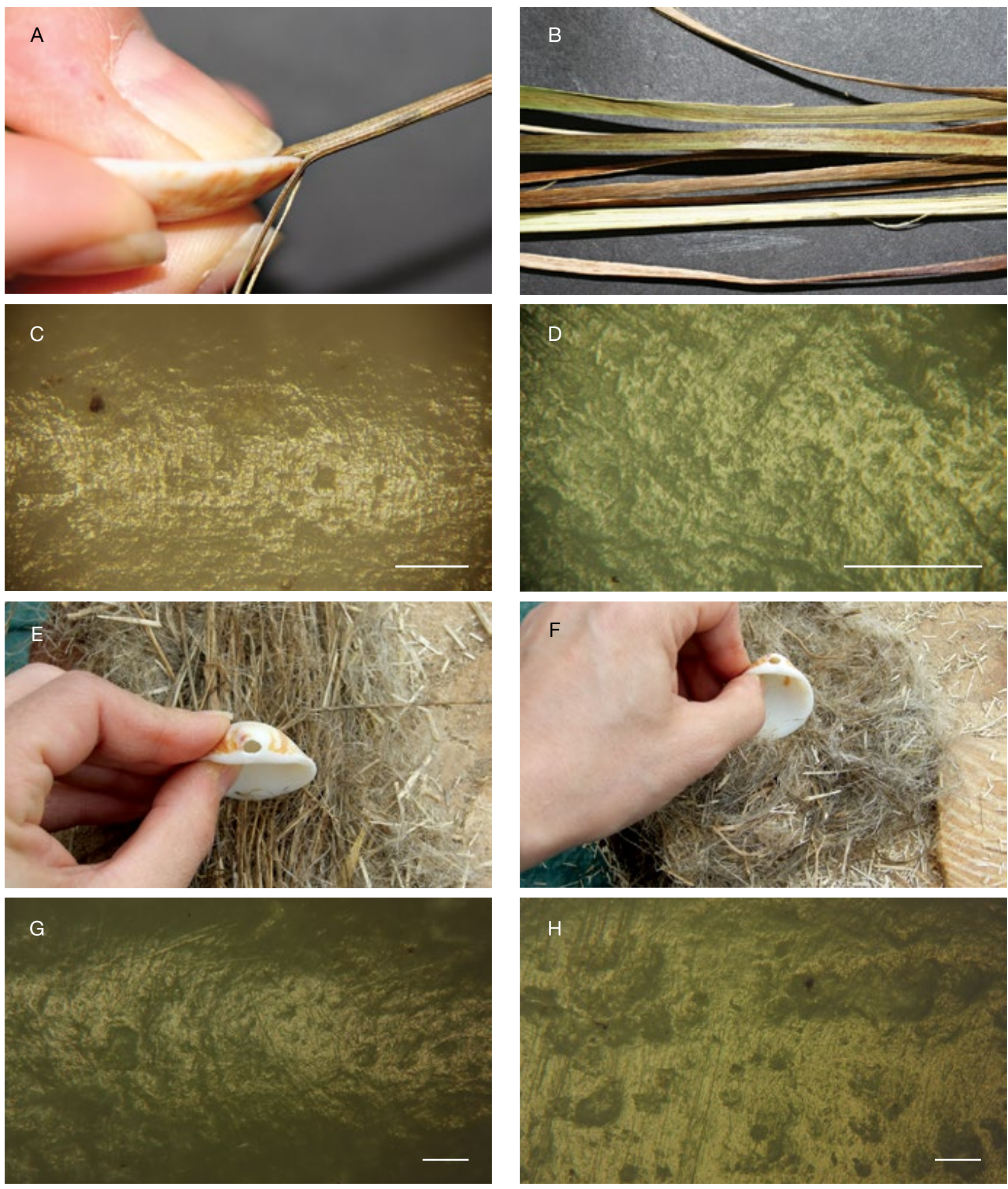

FIG. 6. - A, working mode; B, results obtained; C, D, experimental shell surface used to process rushes (separation of the stems; 15 minutes); E, working conditions; F, results obtained; $\mathbf{G}, \mathbf{H}$, experimental shell surface used to process flax (crushing; 15 minutes). Scale bars: 100 um.

the valves was used to scrape the clay (Fig. 7G). The recorded traces consist of a discontinuously distributed micro-polish on the higher edge, sometimes associated with scratches. It is rounded with a compact fabric and a smooth texture. The contour is irregular, with medium brightness and relatively invasive extension. Scratches are not present on the whole edge, and their density is scattered and dense. They are long, fine and continuous, and parallel or subparallel to each other. 

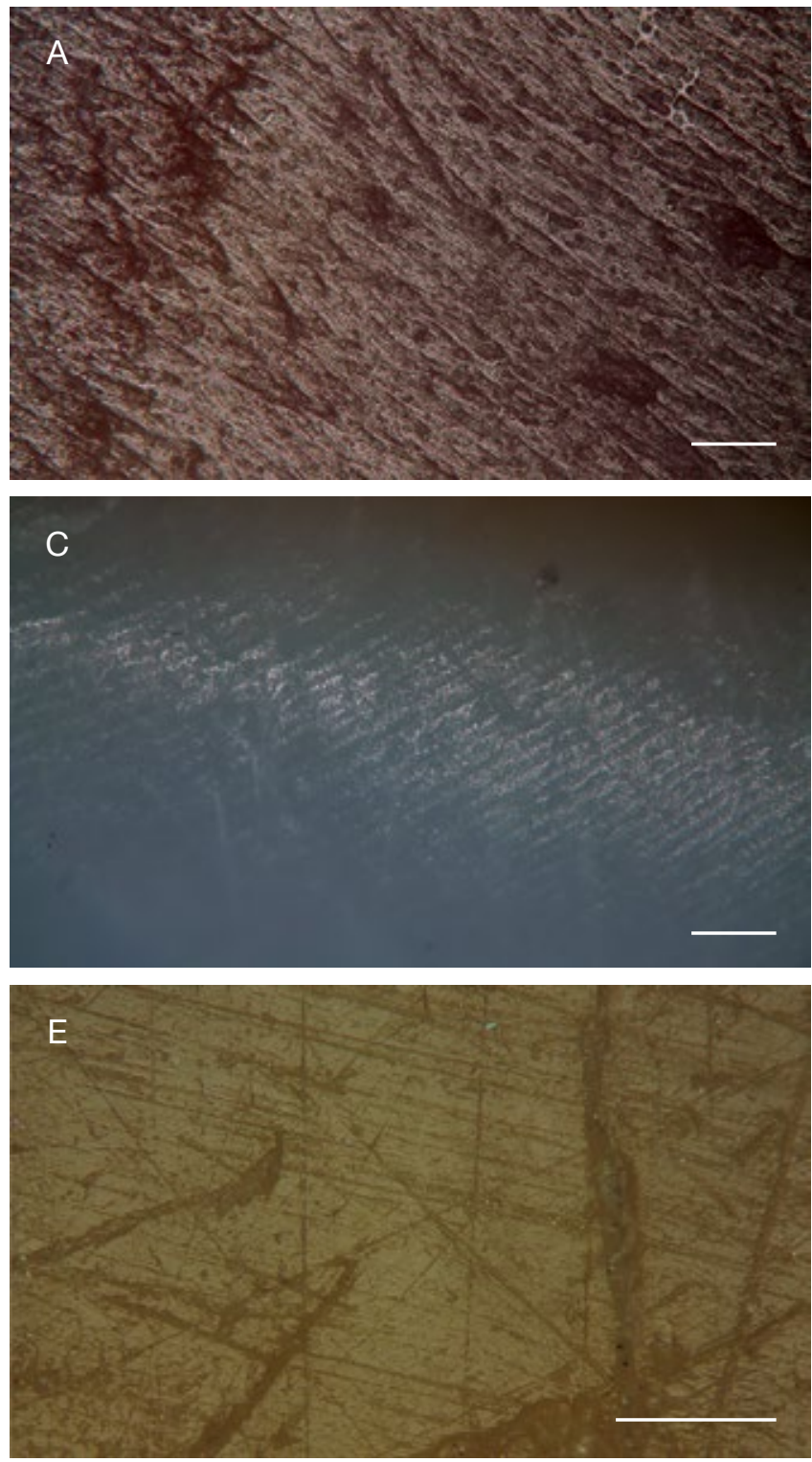

G

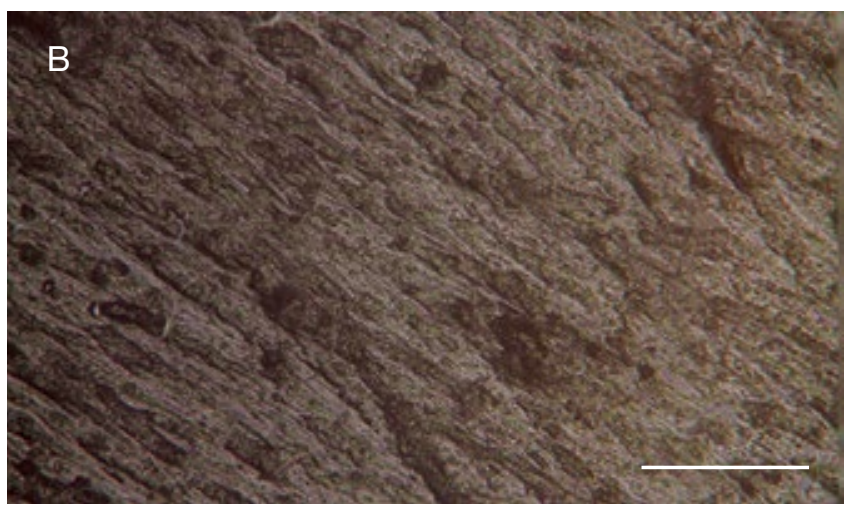

D

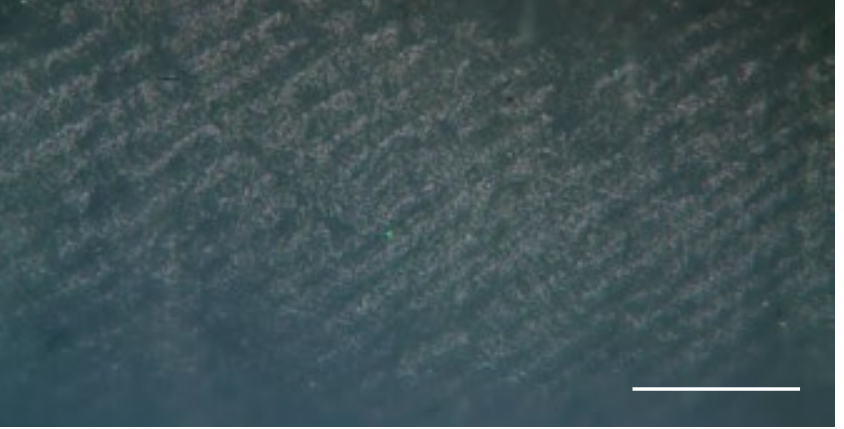

F

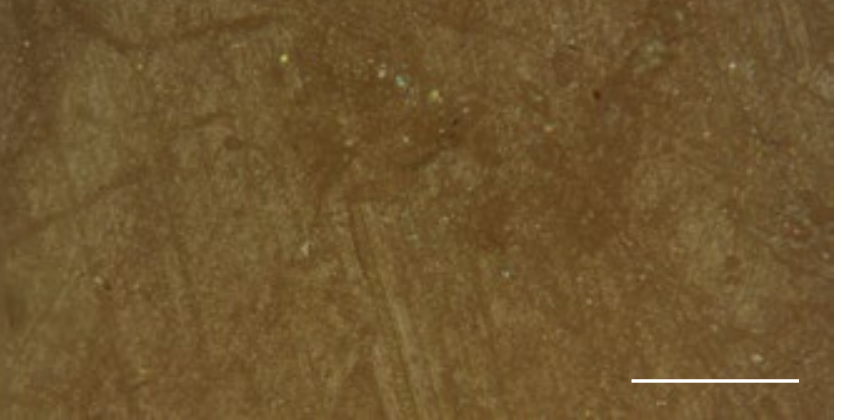

FIG. 7. - A, B, experimental shell surface used to process clay with the dorsal face of valves (smoothing; 15 minutes); C, D, experimental shell surface used to process clay with the edge of valves (smoothing; 15 minutes); E-G, experimental shell surface used to process clay with the dorsal face of valves (smoothing; 1 month). Scale bars: $100 \mu \mathrm{m}$.

\section{Mineral matter, ochre}

The experimentation involved the use of valves as containers for mixing crushed ochre with a sticky substance, to prepare the mixture for use.
The emulsion was manufactured with egg white, respecting the results of the analyses conducted on the pigments present in the Domus de Janas, a set of Neolithic tombs in Sardinia (Cariati et al. 1981; Rampazzi et al. 2002). Two experiments 

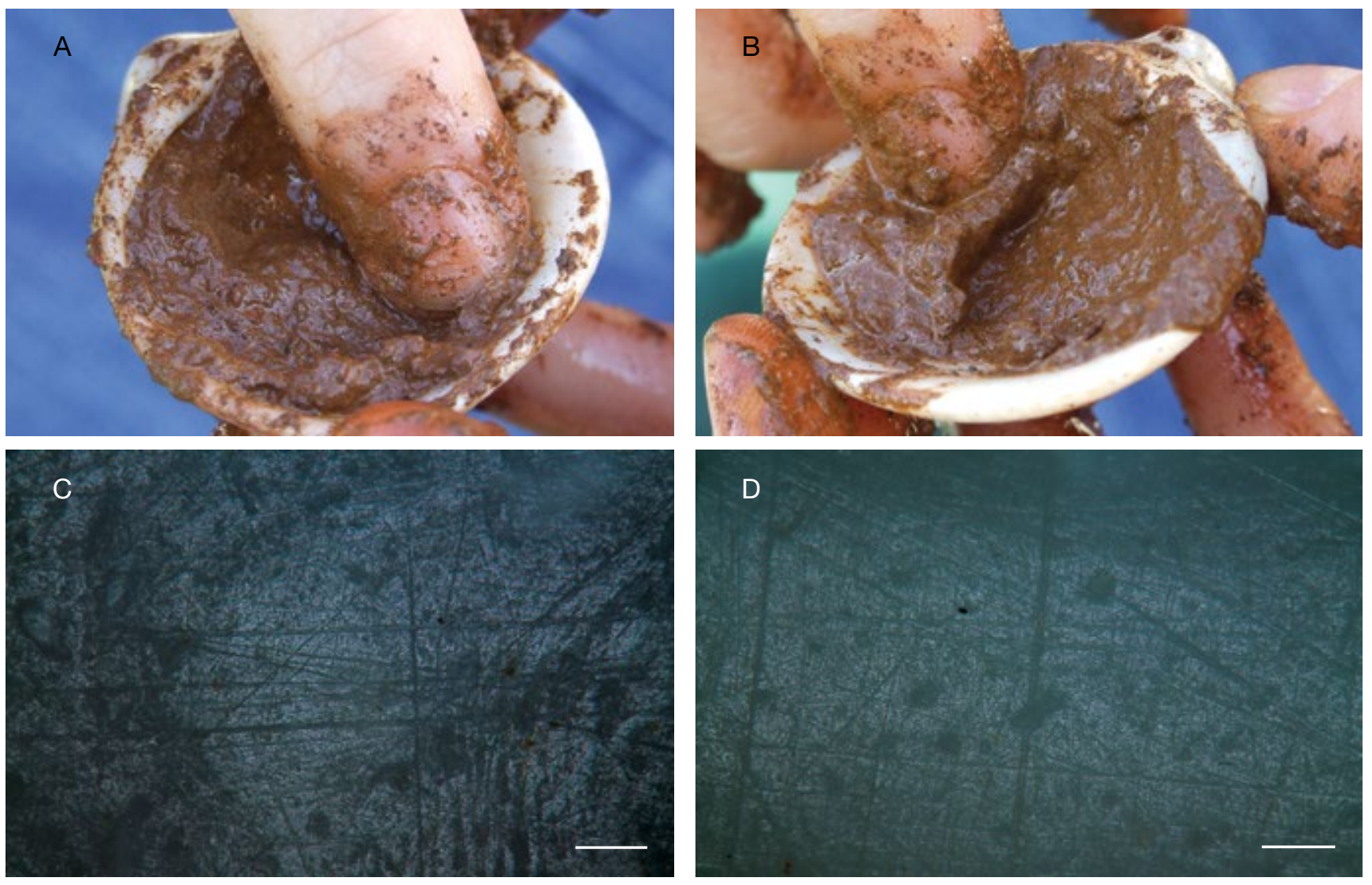

FIG. 8. - A, B, use of shells as containers (mixing the crushed ochre with a sticky substance; 1 hour); C, D, experimental shell surface. Scale bars: 100 $\mu$ m.

were carried out in which ochre was mixed and applied with the fingers (Fig. 8A, B).

The valves present well developed microtraces. The micropolish is characterized by medium brightness and a vague contour. Its micro-topography is homogeneous and its microrelief is regular and smooth, with a soft texture. After half an hour of activity, the fabric is loose with a progressive contour. The scratches are long, broad and deep. The bottom is smooth and, in certain cases, it presents micro-scratches. More prolonged activity, for one hour, results in the formation of a tighter micro-polish on an area of the hinge where we can distinguish much denser and deeper scratches with random orientation and organization (Fig. 8C). Scratches are almost absent from the edges and polish is not developed (Fig. 8D).

\section{RESULTS: ANALYSIS OF THE ARCHAEOLOGICAL FINDS}

STATE OF CONSERVATION OF THE ARCHAEOLOGICAL FINDS The overall state of conservation of the shell pieces from Cuccuru is Arriu is average. The presence of concretions, mostly on the ventral and the dorsal face, can limit the observation of the pieces. However, these alterations usually only occupy limited portions of the surface and they are occasionally located on the umbo or on the hinge, more rarely on the edges. In most cases, the dorsal surface only bears small concreted areas while the ventral side is affected by more compact concretions. The observation of the zones without concretions was often sufficient for identifying traces of use.

\section{FUNCTIONAL ANALYSIS}

The macroscopic and microscopic analysis of the Glycymeris shells found in the Ozieri structures (or Ozieri I) (65 valves) resulted in the identification of use-related traces on $18.46 \%$ of the remains (12 valves) (Table 3 ). In addition, we observed 20 valves with suspension use-wear traces pointing to their use as ornamental objects (Fig. 9).

This proportion may seem surprising as, a priori, all the valves were brought to the site to be used. However, it is essential to take into account the poor state of conservation of the remains and the absence of specific studies on the characterization of the post-depositional traces on the shells. These factors limit the study and call for extreme caution with the interpretation of the analysis.

The valves present traces of use on part of the dorsal face (3 valves) and on the edge (7 valves). On these same valves, it was seldom possible to identify valves presenting traces of use related to transformation and traces of suspension on the umbo (2 valves).

The three valves with traces of use on the dorsal or ventral face present wear related to contact with a mineral matter (Figs 10-12). For two of them, the use-wear traces are com- 
TABLE 3. - Numerical and percentage distribution of the number of remains (NR) from Ozieri I of Cuccuru s'Arriu (Cabras, Italy), assigned to different types of use-wear traces (ornamental objects and instruments) and localization of the use-wear on the valves.

\begin{tabular}{|c|c|c|c|c|c|c|c|}
\hline Species & NR & $\begin{array}{l}\text { Absence of use- } \\
\text { wear traces (NR) }\end{array}$ & $\begin{array}{l}\text { Absence of use- } \\
\text { wear traces (\%) }\end{array}$ & $\begin{array}{l}\text { Use-wear traces } \\
\text { localized on the } \\
\text { dorsal or ventral } \\
\text { face (NR) }\end{array}$ & $\begin{array}{l}\text { Use-wear traces } \\
\text { localized on the } \\
\text { edge (NR) }\end{array}$ & $\begin{array}{l}\text { Use-wear traces } \\
\text { of suspension } \\
\text { and of utilisation } \\
\text { as instrument } \\
\text { (NR) }\end{array}$ & $\begin{array}{l}\text { Use-wear } \\
\text { traces of } \\
\text { suspension } \\
\text { (NR) }\end{array}$ \\
\hline $\begin{array}{l}\text { Glycymeris glycymeris/ } \\
\text { pilosa (Linnaeus, } 1758 \text { ) }\end{array}$ & 43 & 21 & 48,84 & 1 & 7 & 1 & 13 \\
\hline Glycymeris sp. & 13 & 7 & 53,85 & 2 & - & - & 4 \\
\hline $\begin{array}{l}\text { Glycymeris nummaria } \\
\text { (Linnaeus, 1758) }\end{array}$ & 9 & 5 & 55,56 & - & - & 1 & 3 \\
\hline Total & 65 & 33 & 52,75 & 3 & 7 & 2 & 20 \\
\hline
\end{tabular}

A
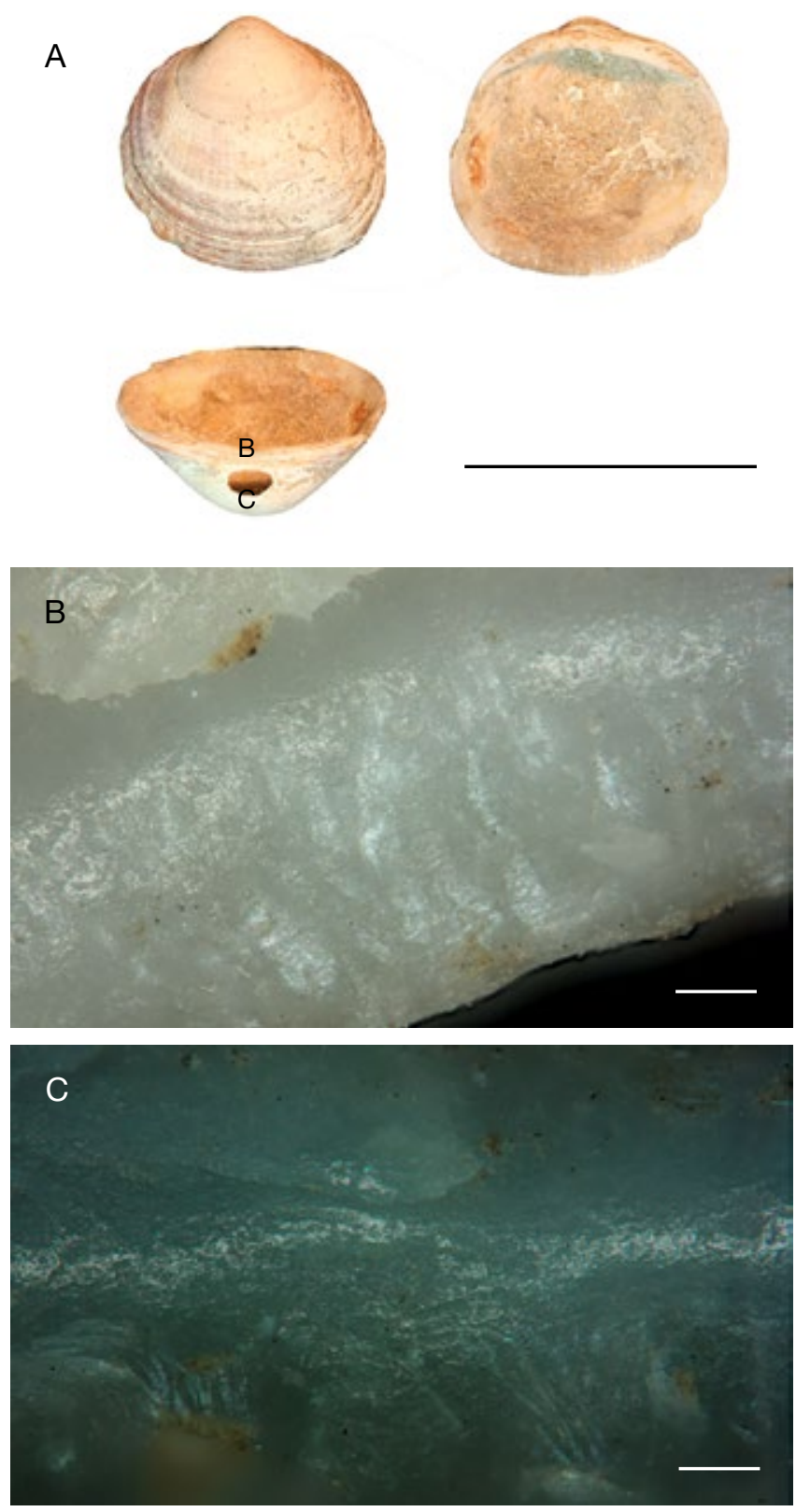

FIG. 9. - A, Archaeological shell with use-wear traces of suspension (Cuccuru s'Arriu, Cabras, Italy); B-C, use-wear traces localized on the edge of natural perforation (B) and on the hinge (C). Scale bars: A, $5 \mathrm{~cm}$; B, C, $100 \mu \mathrm{m}$. parable to those produced in experiments by smoothing fresh clay but contact with other substances of mineral origin can also be considered (Figs 10-11). One of these valves presents red dye traces (ochre?) on the dorsal face (Fig. 10B-D); the largest quantity of dye is on the upper edge whereas small traces are dispersed on the dorsal face. The use-wear traces are also distributed on the dorsal face. The micro-polish is not very developed: it is heterogeneous with an irregular flat microrelief and with a compact fabric and soft texture; the contour is progressive, with weak brightness and a marginal extension. The scratches are long, fine and not very deep, dense and parallel to each other. Their orientation indicates a transverse movement in relation to the upper edge.

Another valve bearing use-wear traces related to smoothing clay presents different polish density and scratches with respect to the localization of the traces (Fig. 11): the polish is more accentuated in the central part of the valve and less developed in the peripheral zone. The orientation of the scratches shows that the valve was used for a transverse and longitudinal movement compared to the upper edge.

The third valve only presents localized traces of use on the hinge and on a very limited zone on the edge, on the ventral face (Fig. 12). A polish of weak brightness, with an heterogeneous microtopography and an irregular flat microrelief, a scattered fabric and grainy texture, progressive contour and relatively marginal extension, is accompanied by long secant scratches, of medium width and depth, with furrowed and shiny bases. These traces are similar to those produced in the experiments using the valves as containers for mixing a mineral substance with a natural binder (egg white).

Seven shells present traces of use on the edge, but only four of these were interpreted. They show very different characteristics in terms of localization, distribution and extension. It was only possible to identify the worked matter in contact with the valves on five zones.

One of them presents use traces related to friction against a mineral material (Fig. 13B). It presents linearly distributed traces on the edge of the ventral face, in a central position, which extend to $1 \mathrm{~cm}$ inside the valve. The polish is not very intense, of low to medium brightness, with a grainy texture and a scattered and scattered fabric. The scratches are perpendicular, very broad and with a furrowed base. The edge bears a rounded polish with a linear distribution, a scattered fabric 
A
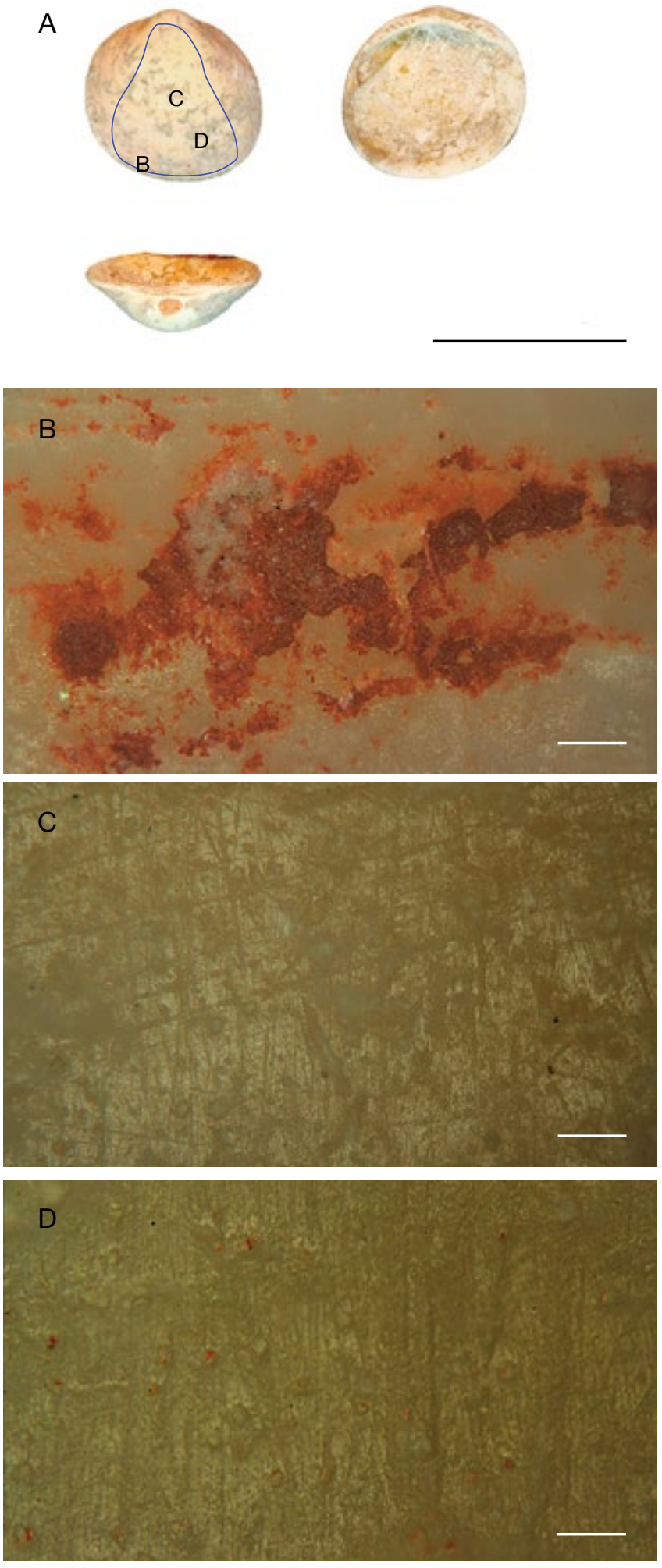

FIG. 10. - A, Archaeological shell with use-wear traces (C-D) and red-dye traces (ochre?) (B) on the dorsal face (Cuccuru s'Arriu, Cabras, Italy) related to contact with a mineral matter, clay. Scale bars: A, $5 \mathrm{~cm}$; B, C, D, $100 \mu \mathrm{m}$.

and an irregular contour, on the higher zones. This zone also presents small circular depressions. These traces could correspond to the scraping of a harder mineral material than clay.
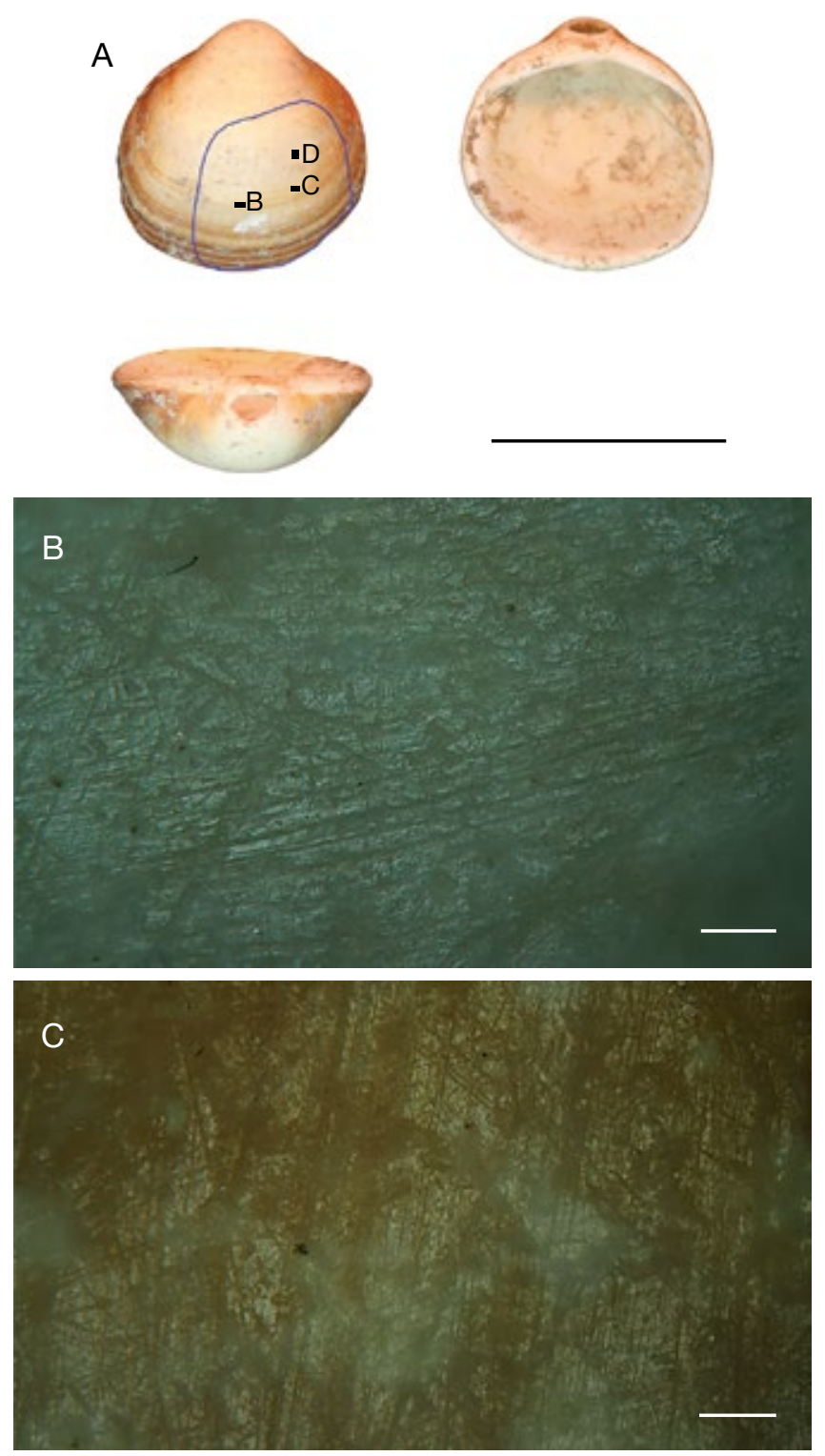

D

FIG. 11. - A, Archaeological shell with use-wear traces (B-D) on the dorsal face (Cuccuru s'Arriu, Cabras, Italy) related to contact with a mineral matter, clay. Scale bars: A, $5 \mathrm{~cm}$; B, C, D, $100 \mu \mathrm{m}$.

A second valve presents mineral colouring residues on the ventral face, near the upper edge (Fig. 14B); the polish and the scratches located near the higher edge of the dorsal face 

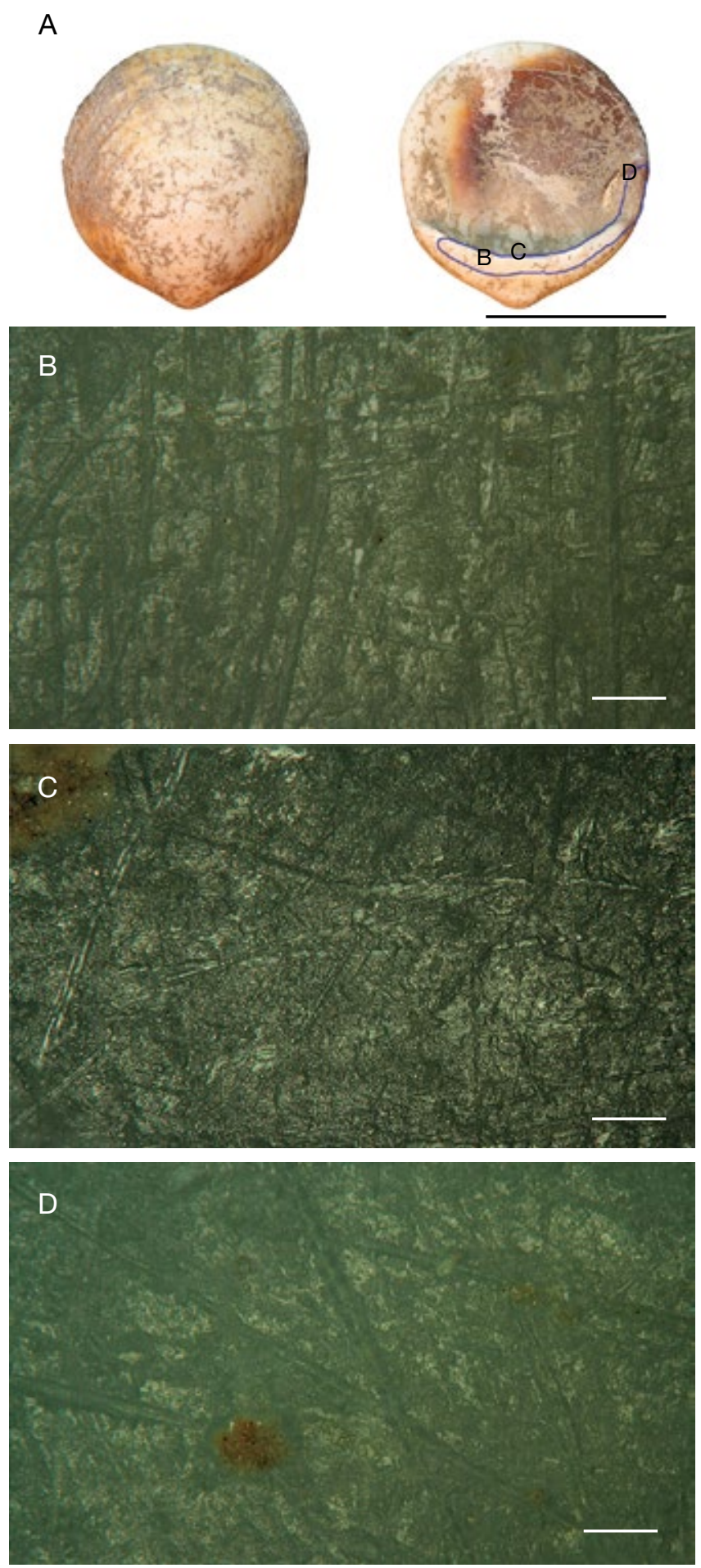

FIG. 12. - A archaeological shell with use-wear traces (B-D) on the ventral face (Cuccuru s'Arriu, Cabras, Italy) related to contact with a mineral matter: utilization as a container for mixing mineral substances. Scale bars: A, $5 \mathrm{~cm}$; $\mathrm{B}, \mathrm{C}, \mathrm{D}, 100 \mu \mathrm{m}$

are however not linked to an activity with ochre or mineral substances. These traces are not developed enough or sufficiently characteristic (Fig. 14C) to be attributed with certainty to one of the experimental activities of our comparative corpus.
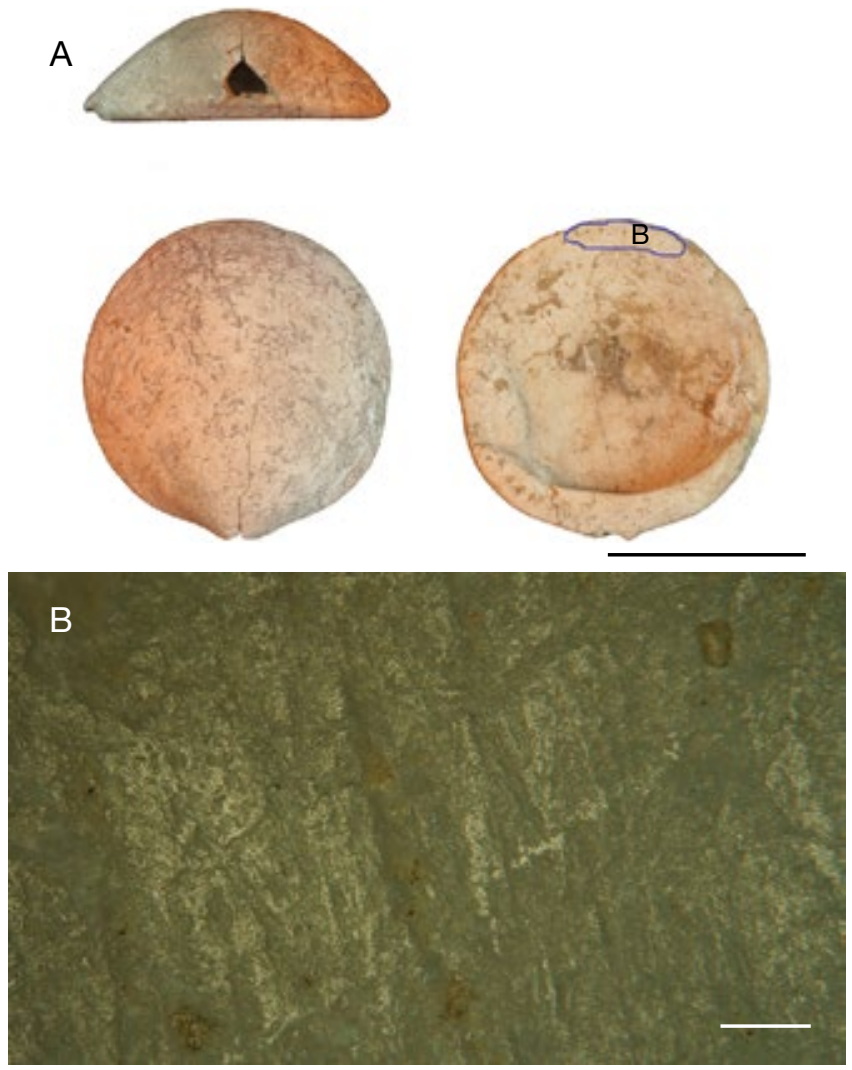

FIG. 13. - Archaeological shells with use-wear traces on the ventral face (Cuccuru s'Arriu, Cabras, Italy) related to contact with an indeterminate mineral matter. Scale bars: A, $5 \mathrm{~cm}$; B, $100 \mu \mathrm{m}$.

Nevertheless, the absence of perforation and the localization of the residues seem to imply that the presence of the dye is not related to the decoration of the valve, or its use as a pendant or decorative object. We can thus assume that the valve may have been used as a small container to mix dye for a short period of time. We saw, through our experiments, that this activity leaves very few traces, even after 30 minutes or one hour of use. This is however only a supposition.

The contact with medium-soft material (soft woody plant matter, dry skin) is observed on the edge of two valves (Fig. 14C, E-H; Fig. 15).

A large-sized Glycymeris valve $(70 \mathrm{~mm}$ long, $71 \mathrm{~mm}$ wide and $22 \mathrm{~mm}$ thick) presents a hole of natural origin on the umbo (Fig. 14D). Traces of use are localized on the upper edge, in a central position, over a length of $30 \mathrm{~mm}$. Correspondingly, the traces develop over a few millimetres from the edge towards the ventral face of the valve. This localization indicates that the valve was used at a vertical or slightly oblique angle.

The traces (Fig. 14H) extend over the whole width of the edge. They are characterized by a polish on the homogeneous zones of the microtopography with a regular rounded microrelief and a tight fabric and by very fine scratches of medium to superficial depth. The latter are parallel to each other and are perpendicular in relation to the completely blunted working edge. The polish on the ventral face is particularly marked 
A
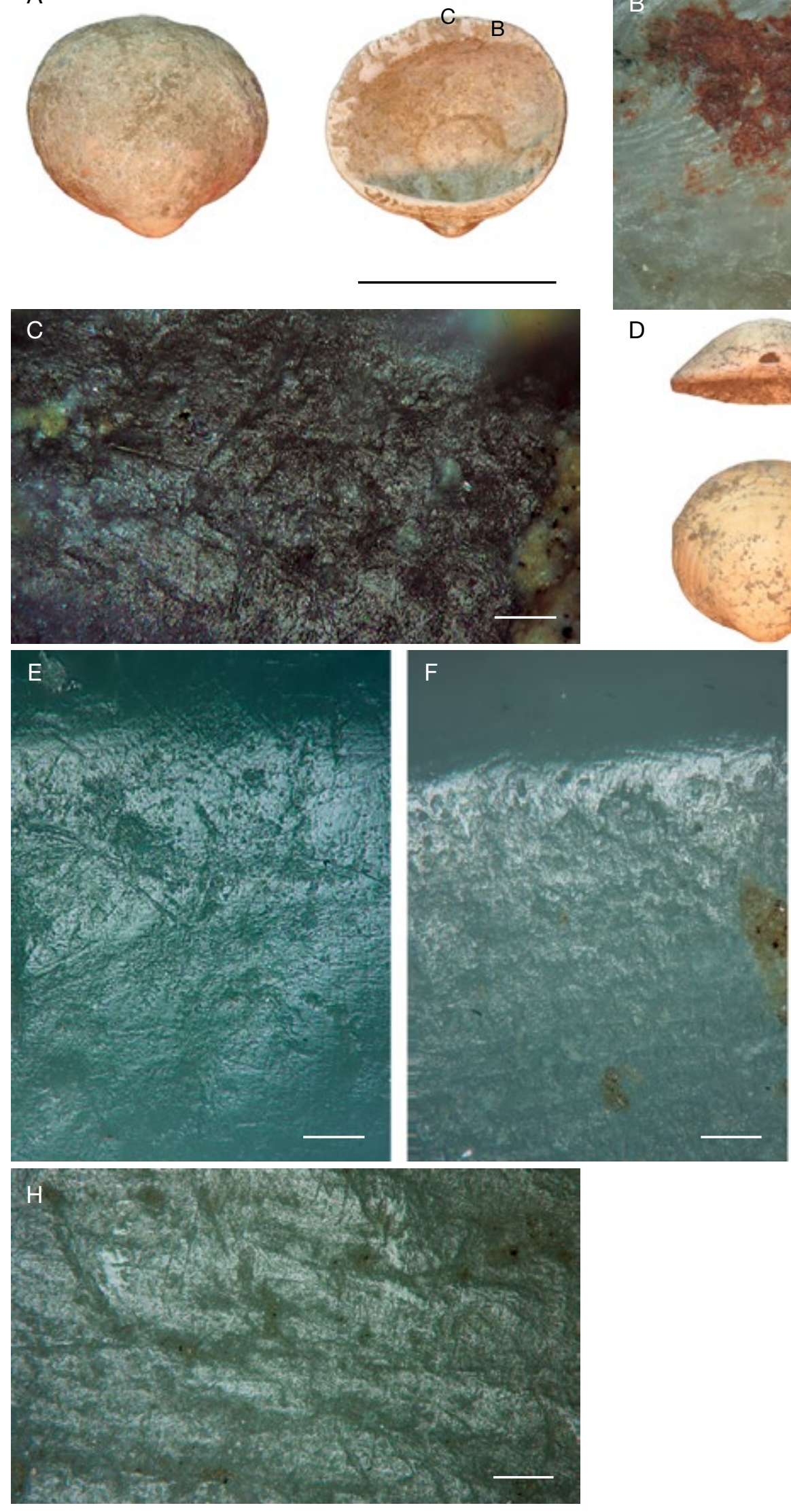

FIG. 14. - A, archaeological shells with use-wear traces on the edge (Cuccuru s'Arriu, Cabras, Italy); B, valve with mineral colouring residue on the ventral face, near the upper edge; $\mathbf{C}$, indeterminate use-wear traces; $\mathbf{D}$, valve with use-wear traces $(\mathbf{E}-\mathbf{H})$ related to contact with plant matter. Scale bars: A, D, $5 \mathrm{~cm}$; B, C,

$\mathrm{E}-\mathrm{H}: 100 \mu \mathrm{m}$.

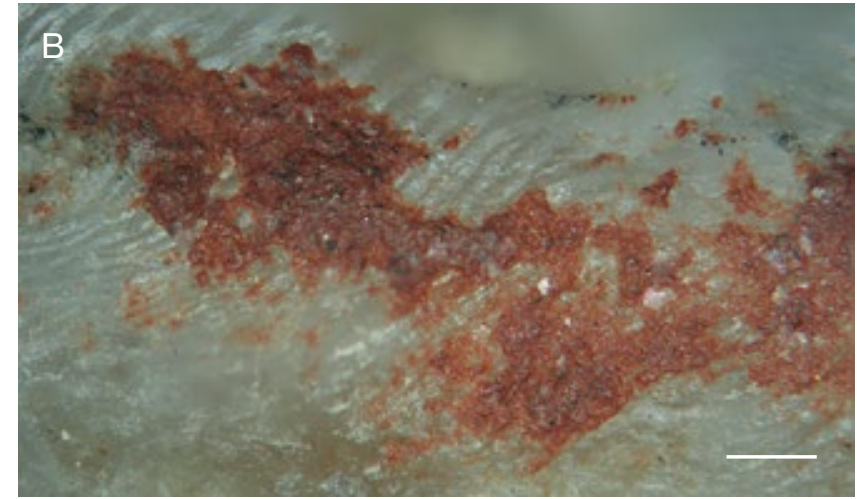

$\mathrm{D}$
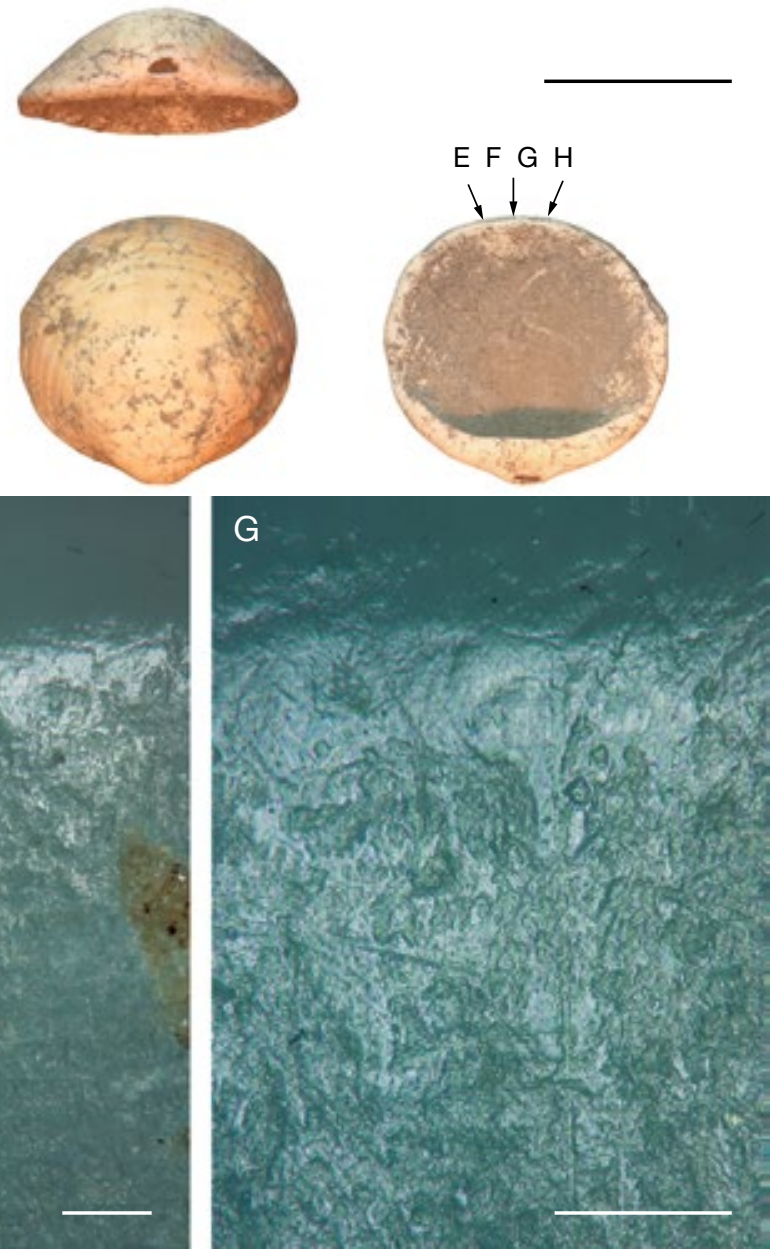

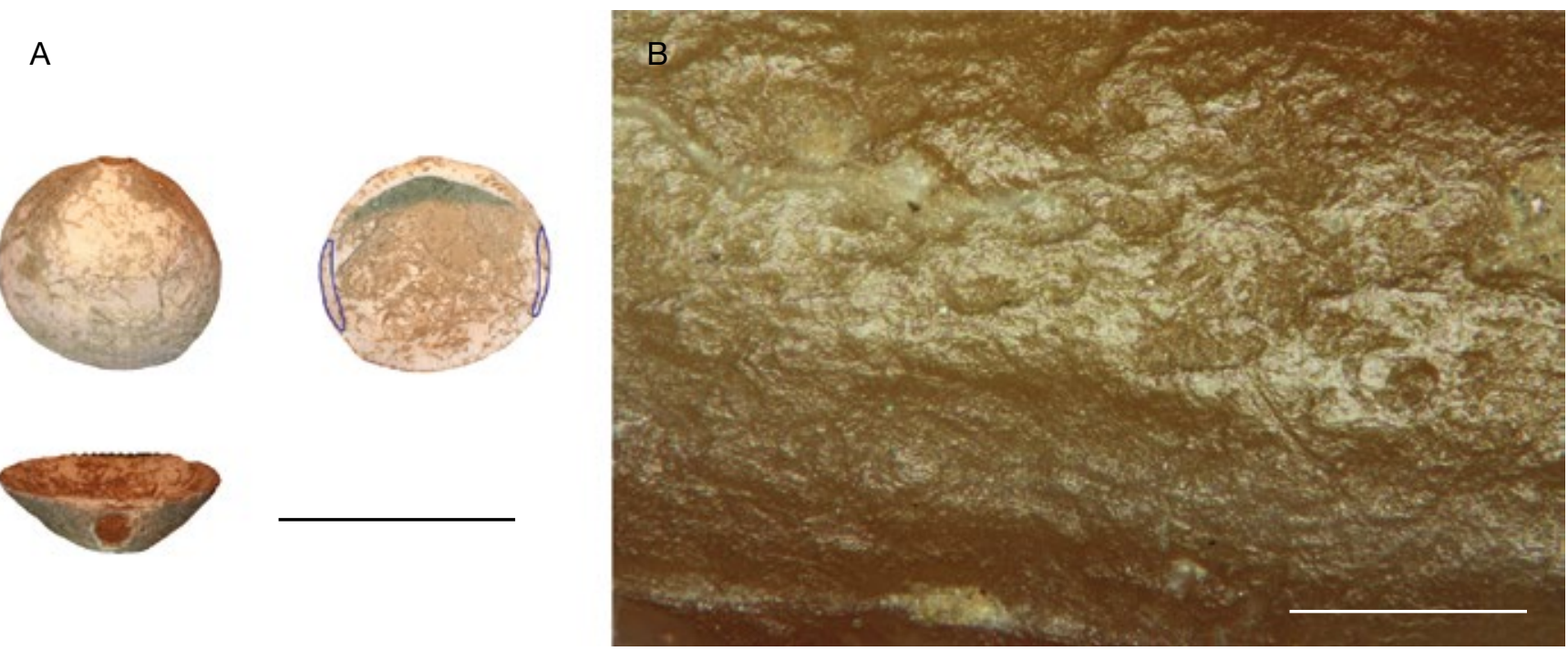

FIG. 15. - A, archaeological shells with use-wear traces on the edge (Cuccuru s'Arriu, Cabras, Italy); B, use-wear traces related to contact with plant matter. Scale bars: A, $5 \mathrm{~cm}$; B, $100 \mu \mathrm{m}$.

on the edge and diminishes towards the interior of the valve (Fig. 14F). The scratches only affect the part nearest the edge and are more randomly oriented (Fig. 14E). The other characteristics are identical to those described on the edge. The morphology of the polish and the scratches are similar to the traces produced in experiments by working plant materials (polish and scratches located on the edge) and those produced by friction against more supple materials, such as skin (ventral face: more invasive polish, rarer scratches). There is no doubt that the comparative corpus used for the analysis of the archaeological remains is not yet sufficiently rich to accurately interpret all the traces. Nevertheless, it was possible to identify the active part and, in a generic way, the material with which it was in contact: in this case, one or several soft and medium-hard materials.

The second valve presents traces on the higher edge and the ventral face as well as on the side edges (Fig. 15). The polish affects the heterogeneous microtopography with a regular rounded microrelief and presents a tightened fabric, with a glossy surface and rare very fine scratches.

One of the two shell valves presented traces related to suspension as well as traces caused by friction with other materials. The latter are comparable to those obtained by smoothing fresh clay (Fig. 16C, D). These traces are localized on an extended zone of the dorsal face, and are parallel or slightly obliquely oriented in relation to the longitudinal axis of the valve. The characteristics of the polish suggest prolonged use because they are similar to those produced during 15 minutes of activity. The scratches are parallel, of variable thickness and depth, and transversely oriented, indicating the direction of the gesture. The hinge and the umbo present a polish and scratches indicating the suspension of the shell.

The second valve bears traces of bifacial use: they occupy a semi-circular part of the valve, parallel to the higher edge of the valve on the dorsal face, and extend towards the centre of the valve with a more significant depth in the central part. They extend a few millimetres from the edge of the ventral face, only covering one linear zone out of 1 centimetre (Fig. 16E). These traces remain unspecified.

\section{DISCUSSION}

\section{CONTRIBUTION TO SHELL INDUSTRY STUDIES}

Our study is part of recent scientific research on use-wear traces on shells (Mansur \& Clemente-Conte 2009; CuencaSolana et al. 2010, 2013, 2015; Tumung et al. 2015), and brings new elements concerning the Glycymeridae family: Glycymeris glycymeris (Linnaeus, 1758), Glycymeris pilosa (Linnaeus, 1767) and Glycymeris nummaria (Linnaeus, 1758).

The macroscopic and microscopic observation of the natural valve surfaces resulted in the identification of parameters for distinguishing natural microscopic traces from human-made ones: localization, texture and fabric of micro-polishes and the localization, density and morphology of striations. The valves of this species have a crossed-lamellar structure, with high density and rigidity, and moderate resistance to deformation and to hardness (Taylor \& Layman 1972). Due to these features, scraping or smoothing soft or medium-hard materials leaves practically no macrotraces, and only microscopic analysis can help to characterize use-wear traces. The valves were used for various activities on different raw materials (animal, plant and mineral materials), and the combination of a low-power approach using a metallographic microscope and a mediumpower approach with stereomicroscopic observations, led to the characterization and differentiation of the micro-polishes and striations resulting from the various activities.

The experimental use-wear observed on valves used for processing skin generally consists of a bright polish with a compact fabric and an invasive extension associated with 
A
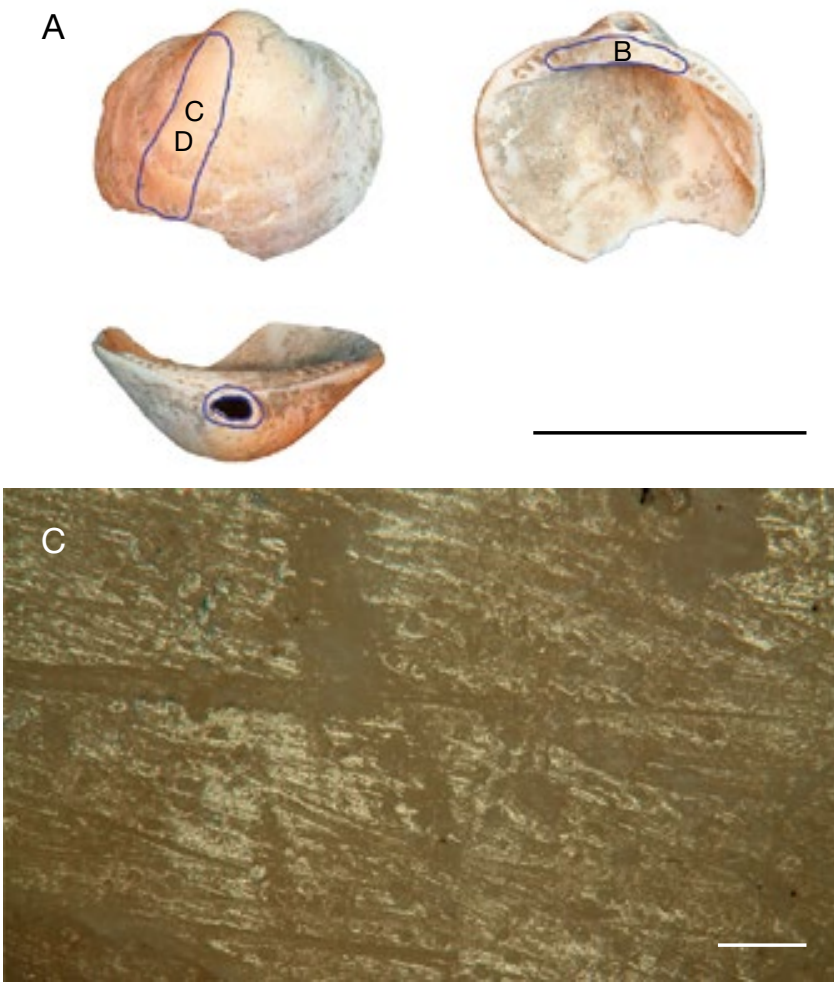

E
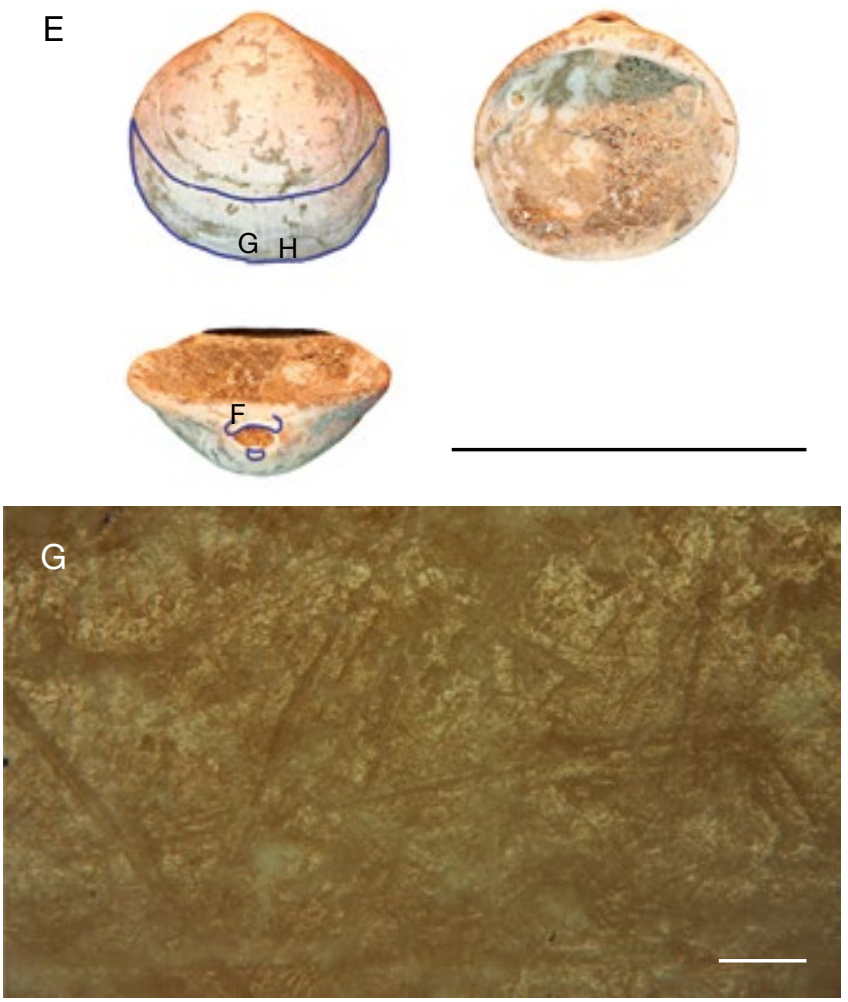
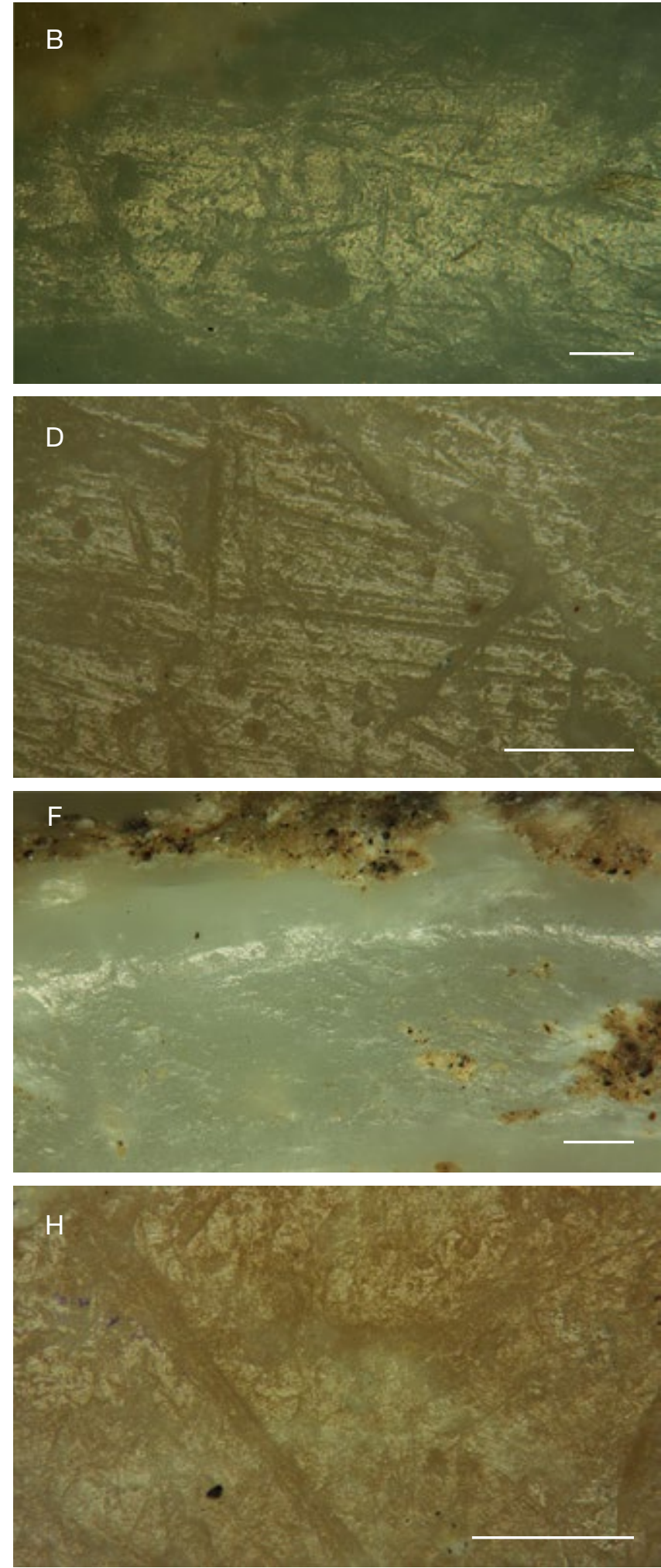

FIG. 16. - Archaeological shells with use-wear traces on the edge (Cuccuru s'Arriu, Cabras, Italy). A, valve with use-wear traces (B, C, D) related to contact with a mineral matter, clay; $\mathbf{E}$, Valve with use-wear traces $(\mathbf{F}, \mathbf{G}, \mathbf{H})$ related to the contact with indeterminate mineral matter. Scale bars: $100 \mu \mathrm{m}$.

long striations. The differences observed between the usewear traces produced during the softening and scraping of dry skin include a more regular surface and more variability in the width and depth of striations for the softening activity.
The scraping of dry skin with the addition of ochre tends to increase the width and depth of the striations, which present irregular edges, making the surface slightly grainy. Processing plant materials results in use-wear traces characterized by a 
grainy polish generally only extending to the areas in direct contact with the worked material when the woody material is hard and dry (wood, flax), and extends over a much larger surface, using the same working angle, when the material is soft and fresh (bark, rush). The same characteristics appear to have induced a higher degree of surface erosion for the valves used for working wood and flax. The striations also present unusual characteristics: they are generally superficial and short, but are denser, deeper and longer after processing boxwood and flax wood. The use-wear traces produced by processing mineral materials are characterized by a dull, nearly opaque polish, and by the presence of long, deep and intersecting striations.

Although these preliminary results are very promising, these experiments are currently limited in terms of variants (processing activities, inclination of tools in relation to the worked surface, working time), and in terms of the number of valves used for each experiment and the taxa considered for working animal and vegetal materials. These should be multiplied and increased in order to characterize use-wear traces with greater precision.

\section{THE ROLE OF THE SHELL INDUSTRY IN THE EXPLOITATION OF MARINE RESOURCES: NEW ACQUISITIONS IN THE FINAL NEOLITHIC IN SARDINIA}

The first evidence of the presence of shells collected for nonfood purposes at the Cuccuru S'Arriu site was recorded during archaeozoological studies of Middle Neolithic remains from the first occupation phase of the site (Bignon et al. 2008). Later, the discovery of a large number of shells in the Final Neolithic fauna raised questions as to the role of these remains in the socio-economic activities of these Neolithic groups. The results obtained from the analysis of natural shells and their comparison with the experimental and archaeological valves showed that some shells collected for non-food purposes were used as tools. The valves bear use-wear traces indicating various production activities: smoothing fresh clay, processing plant, animal and mineral materials and the use of valves as containers for mineral materials. These results thus confirm the initial assumption that valves were collected for purposes related to the shell industry.

During the late Neolithic, the inhabitants of the Cuccuru S'Arriu site exploited other raw materials of animal origin, such as bone and antler (Manca 2013). The former is extremely important for the production of sharp instruments and, to a lesser extent, for the production of blunt objects. In contrast, all of the tools used for scraping and smoothing are almost exclusively obtained from shells. This raw material also presents specific characteristics at all stages of the technical production system, from acquisition to use. Bone and horn raw materials are obtained through breeding (for domestic species) and hunting (for wild species), whereas shell valves are acquired by collecting them on the shoreline.

Valves could have potentially been collected in the vicinity of the site, on the beaches of the central-western coast of the island. Valves of the Glycymeridae family were identified on Pesaria beach, to the south of the current city of Oristano and at three other beaches located outside the Gulf (Spano et al. 2002, pers. obs.): Tharros (Tharros West), San Giovanni di Sinis and Su Maimoni (Fig. 1). The location of potential collection zones contributes to the identification of the territories frequented by the inhabitants of Cuccuru s'Arriu. However, the introduction of these raw materials to the site may also result from exchanges with other communities: archaeological evidence on the Sinis Peninsula points to an area of intense attendance during Ozieri I (Stiglitz 1998: 30; Melis 2011). In any event, we can consider that, unlike bone raw materials, shells are available outside the site and therefore access to them is not direct. In addition, from an economical point of view, valve collecting requires a certain investment in terms of human resources.

However, the technical investment for the production of finished shell objects is minimal. On account of the characteristics of the raw material (morphology, hardness and resistance), the valves are suitable for productive activities without extensive modifications. Direct shell shaping only concerns rare cases (20 pieces out of 65), and modifies the active part of the valve, the edge, by abrasion or direct percussion (for technical vocabulary see Averbouh 2000, 2001, 2010). This transformation concerns the valves with no use-wear traces (11 pieces out of 33), with abrasion marks on the edge (1 piece), for creating a side-scraper or for the perforation of umbo (10 pieces). Moreover, the valves used as ornamental objects ( 5 pieces out of 20 ) and those used as tools ( 4 pieces out of 12) present marks showing anthropogenic perforation. The first case (presence of technical marks and absence of use-wear traces) can be explained by two hypotheses: the first is based on the state of preservation of the pieces, that is, the non-preservation of use-wear traces; the second, on the transformation of the raw material during a previous phase of use. The second case (anthropogenic perforation and use of valves as ornamental objects) detects a compatibility between transformation and use. The third case (anthropogenic perforation and the use of the valve as a tool) suggests that for certain valves, the primary objective is not transformation (perforation, then suspension), but the secondary use of shells as tools. This suggests that certain valves could have been transformed and stocked as raw material reserves and used occasionally for purposes other than those for which they were initially collected and shaped.

This hypothesis is supported by economic aspects connected to raw material productivity: each valve can only produce one tool or one ornamental object. This low productivity is accentuated by the availability of the raw material (the shells are not renewable directly on the site).

These elements converge to define the techno-economical aspects of the Glycymeridae industry and provide important data concerning the management of marine resources. It is also important to bear in mind that the accessibility of collection areas is not the only factor to consider in determining raw material availability. Supply rhythms and raw material management in the society must also play an important role. We do not know who collected the valves, when or how this type of resource was distributed. As for supply rhythms, no 
archaeozoological or palynological data point to a seasonal use of the site of Cuccuru s'Arriu, although this hypothesis is advanced for the Middle Neolithic phase (Bignon et al. 2008).

\section{CONCLUSIONS}

The identification and analysis of Glycymeris shells bearing natural erosion marks among the faunal remains of Cuccuru s'Arriu show the techno-economic importance of this industry in Final Neolithic societies. This analysis also enhances our knowledge of the exploitation of marine resources and raises question as to the accessibility and availability of shell materials, the potential exploitation of territories and potential exchanges between groups. These data illustrate the relationship between the inhabitants of a site near the coast, and show the necessity of extending these studies to other inland sites in order to define the role of the shell industry on this insular island during the Final Neolithic and successive phases (Manca 2014).

On a wider scale, these initial results call for more detailed analyses of the shell industry in the western Mediterranean in order to define their relationship with other technical systems and their role in the technical and economic activities of prehistoric societies, at a regional and trans-maritime level.

\section{Acknowledgements}

This research was funded by a doctoral grant from the Autonomous Region of Sardinia (Programma Master and Back, Alta Formazione, Anno 2007). I wish to thank Patrizia Manca and Louise Byrne for the translation of the manuscript into English. I also express my gratitude to the two anonymous reviewers for their comments and suggestions.

\section{REFERENCES}

ATtEnBROW V. 2012. - The Aboriginal prehistory and archaeology of Royal National Park and environs: a review. Proceedings of the Linnean Society of New South Wales 134: B39-B64.

ATZENI E. 1962. - I villaggi preistorici di San Gemiliano di Sestu e Monte Olladiri di Monastir presso Cagliari e le ceramiche della «facies» di Monte Claro. Studi Sardi XVII: 3-216.

ATZENI E. 1975. — Nuovi idoli della Sardegna prenuragica (Nota preliminare). Studi Sardi XXIII: 1-51.

ATZENI E. 1978. — La Dea Madre nelle culture prenuragiche. Studi Sardi XXIV: 1-61.

AverbouH A. 2000. - Technologie de la matière osseuse travaillée et implication palethnologique; l'exemple des chaînes d'exploitation du bois de cervidé chez les magdaléniens des Pyrénées. PhD dissertation, Université de Paris I, 500 p.

Averboun A. 2001. - Methodological specifics of the technoeconomic analysis of worked bone and antler: mental refitting and methods of application, in CHOYKE A. M. \& BARTOSIEWICZ L. (eds), Crafting Bone: Skeletal Technologies through Time and Space. Proceedings of the 2nd meeting of the (ICAZ) Worked Bone Research Group Budapest, 31 August-5 September 1999. British Archaeological Reports International Series 937: 111-121.

Averboun A. (ed.) 2010. - Multilingual lexicon of bone industry version 1. Part 1: Français, English, Italanio, Español. GDRE PREHISTOS Archaeological Studies I. http://gdreprehistos. cnrs.fr/medias/fichier/gdre-prehistos-archaeological-studies1_1355233470300-pdf last consultation: 08/11/2016.

BRADFIELD J. 2015. - Use-trace analysis of bone tools: a brief overview of four methodological approaches. South African Archaeological Bulletin 70 (201): 3-14.

Bernabò BrEa L. 1946. - Gli scavi nella caverna delle Arene Candide (Finale Ligure). Parte I, Gli strati con ceramiche. Istituto di Studi Liguri, Bordighera, 296 p.

BEYRIES S. 2008. - Modélisation du travail du cuir en ethnologie: proposition d'un système ouvert à l'archéologie. Anthropozoologica 43 (1): 9-42 + DVD-ROM.

Bignon O., Serrand N., Costa L.-J. \& Lugliè C. 2008. — Les restes culinaires de Cuccuru is Arrius (Oristano, Sardaigne): nouveaux apports à la connaissance des économies néolithiques en domaine littoral. Bulletin de la Société Préhistorique Française 105 (4): 773-785. http://doi.org/10.3406/bspf.2008.13784

Bonomo M. \& AguirRe M. L. 2009. - Holocene molluscs from archaeological sites of the Pampean region of Argentina: approaches to past human uses. Geoarchaeology 24: 59-85. http:// doi.org/10.1002/gea.20254

Cariati F., Piredda G., Serri R. \& Tanda G. 1981. - Analisi chimicomineralogiche di un campione di parete dipinta della domus de janas I di Molia-Illorai (Sassari). Rivista di Scienze Preistoriche XXXVI (1-2): 291-300.

Choi K. \& Driwantoro D. 2007. - Shell tool use by early members of Homo Erectus in Sangiran, central Java, Indonesia: cut mark evidence. Journal of Archaeological Science 34: 48-58. http://doi.org/10.1016/j.jas.2006.03.013

CHRISTIDOU R. 1999. - Outils en os néolithique du nord de la Grèce: étude technologique. PhD dissertation, Université de Paris X, 698 p.

Clemente-Conte I. \& CuenCA-Solana D. 2011. — Instrumentos de trabajo de concha, in BOSCH A., CHINCHILLA J. \& TARRús J. (eds), El Poblat Lacustre del Neolitic Antic de La Draga. Excavacions 2000-2005. Monografies del CASC 9: 137-145.

CourTin J. \& VigiE B. 1987. — Le problème des coquillages à bords dentelés dans la Préhistoire du Midi de la France. Mésogée 47: 93-98.

Cristiani E., Lemorini C., Martini F. \& SARTI L. 2005. Scrappers of Callista chione from Grotta del Cavallo (Middle Paleolithic cave in Apulia): evaluating use-wear potential, in LUIK H., CHOYKE A., BAtey C. \& Lougos L. (eds), From Hooves to Horns, from Mollusc to Mammoth: Manufacture and Use of Bone Artefacts from Prehistoric Times to the Present. Proceedings of the 4th meeting of the ICAZ Worked Bone Research Group, Tallin, 26th-31st of August 2003. Tallin Book Printers, Tallin: 319-324.

CUENCA SOlANA D. 2013. - Utilización de instrumentos de concha para la realización de actividades productivas en las formaciones económico-sociales de los cazadores-recolectores-pescadores y primeras sociedades tribales de la fachada atlántica europea. Tesis Doctorales 4, $445 \mathrm{p}$.

Cuenca Solana D., Cantillo Duarte J. J., Vijande Vila E., Montañés Caballero M., Clemente Conte I. \& Villapando Moreno A. 2013. - Utilización de instrumentos de concha para la realización de actividades productivas en sociedades tribales comunitarias del sur de la Península Ibérica. El ejemplo de Campo de Hockey (San Fernando, Cádiz) y SET Parralejos (Vejer de la Frontera, Cádiz). Zephyrvs 72: 95-111. http://doi. org/10.14201/zephyrus20137295111

Cuenca Solana D., Clemente Conte I. \& Gutiérrez Zugasti I. 2010. — Utilización de instrumentos de concha durante el Mesolítico y Neolítico inicial en contextos litorales de la región cantábrica: programa experimental para el análisis de huellas de uso en materiales malacológicos. Trabajos de Prehistoria 67 (1): 211-225. http://doi.org/10.3989/tp.2010.10037

Cuenca Solana D., GutiérReZ-Zugasti I. \& Clemente-Conte I. 2011. - The use of molluscs as tools by coastal human groups: contribution of ethnographical studies to research on Mesolithic and early Neolithic contexts in Northern Spain. Journal of 
Anthropological Research 67 (1): 77-102. http://doi.org/10.3998/ jar.0521004.0067.105

Cuenca Solana D., Gutiérrez-Zugasti F. I. \& Clemente I. 2014. - Shell tools in an early Neolithic coastal site in the Cantabrian region (northern Spain): experimental program for use-wear analysis at Santimamiñe cave, in SzABÓ K., DUPONT C., Dimitrijevic S., Gómez-Gastélun L. \& Serrand N. (eds), Archaeomalacology: Shells in the Archaeological Record. British Archaeological Reports International Series 266: 101-110.

Cuenca Solana D., GutiérReZ-Zugasti I. \& GonZÁleZ-Morales M. R. 2015. - Use-wear analysis: an optimal methodology for the study of shell tools. Quaternary International December 2015. http://doi.org/10.1016/j.quaint.2015.09.090

DOUKA K. 2011. - An Upper Palaeolithic shell scraper from Ksar Akil (Lebanon). Journal of Archaeological Science 38 (2): 429-437. http://doi.org/10.1016/j.jas.2010.09.026

DrISCOLL E.-G. \& WeLTIN T.-P. 1973. - Sedimentary parameters as factors in abrasive shell reduction. Palaeogeography, Palaeoclimatology, Palaeoecology 13: 275-288.

DUPONT C. 2003. - La malacofaune de sites mésolithiques et néolithiques de la façade atlantique de la France: contribution a l'économie et àl'identité culturelle des groupes concernés. British Archaeological Reports International Series 1571, $439 \mathrm{p}$.

ÉVORA M. 2015. - Use-Wear methodology on the analysis of osseous industries, in MARreiros J. M., Gibaja BAO J. F. \& BiCHO Nuno F. (eds), Use-wear and Residue Analysis in Archaeology, Chapter 8. Springer International Publishing, Cham: 159-170. (Coll. Manuals in Archaeological Method, Theory and Technique). http://doi.org/10.1007/978-3-319-08257-8 8

GRUET Y. 1993. - Les coquillages marins: objets archéologiques à ne pas négliger. Quelques exemples d'exploitation et d'utilisation dans l'Ouest de la France. Revue Archéologique de l'Ouest 10: 157-161. GutiérREZ-Zugasti I. \& CuenCA-SOlAnA D. 2015. — Ornaments from the Magdalenian burial area in El Mirón Cave (Cantabria, northern Spain). Were they grave goods? Journal of Archaeological Science 60: 112-124. http://doi.org/10.1016/j.jas.2015.04.012 Gutiérrez-Zugasti I., CuenCa-Solana D., Rasines del Río P., Muñoz E., Santamaría S. \& Morlote J. M. 2013. - The role of shellfish in hunter-gatherer societies during the Early Upper Palaeolithic: a view from El Cuco rockshelter, northern Spain. Journal of Anthropological Archaeology 32 (2): 242-256. http:// doi.org/10.1016/j.jaa.2013.03.001

Henshilwood C. S., D’ERrico F., Van Niekerk K. L., CoQuinot Y., Jacobs Z., LaURitZen S.-E., Menu M. \& Garcia-Moreno R. 2011. - A 100,000 year-old ochre processing workshop at Blombos Cave, South Africa. Science 334 (6053): 219. http:// doi.org/10.1126/science.1211535

LAMMERS-KEIJSERS Y. 2007. — Tracing traces from present to past: a functional analysis of pre-Columbian shell and stone artefacts from Anse à la Gourde and Morel, Guadeloupe, FWI. Archaeological Studies Leiden University 15, 182 p. http://hdl.handle.net/1887/12489

LEGRAND A. 2005. - Nouvelle approche méthodologique des assemblages osseux du Néolithique de Chypre. Entre technique, fonction et culture. PhD Dissertation, Université de Paris I, 1396 p.

LEROI-Gourhan A. 1945. - Milieu et techniques, évolution et techniques II. Albin Michel, Paris, $480 \mathrm{p}$

LuCERO J M. \& DONALD J. S. 2005. - Shell tool in Early Holocene contexts: studies of early settlements in America Pacific coast of Chile Current Res. The Pleistocene 22: 23-25.

MAICAS RAmOS R. 2008. - Objetos de concha: algo más que adornos en el Neolítico de la cuenca de Vera (Almería), in HERnÁNDEZ Pérez M., Soler Díaz J. \& López Padilla J. (eds), IV Congreso del Neolítico Peninsular II. Diputatiòn Provincial de Alicante, Museo Arqueológico de Alicante, Alicante: 313-319.

MAigrot Y. 1997. - Tracéologie des outils tranchants en os des $\mathrm{Ve}$ et IVe millénaires avant J.-C. en Bassin Parisien: essai méthodologique et application. Bulletin de la Société Préhistorique Française 94 (2): 198-216.
Maigrot Y. 2003. - Étude technologique et fonctionnelle de l'outillage en matières dures animales: la station 4 de Chalain (Néolithique final, Jura, France). Phd Dissertation, Université de Paris I, 284 p.

MANCA L. 2010. - Gli oggetti d'ornamento in conchiglia, in MELIS M. G. (ed.), Usini. Ricostruire il passato. Una ricerca internazionale a S'Elighe Entosu, Carlo Delfino, Sassari: 237-248.

MANCA L. 2011. - Gli oggetti di parure in materia dura animale nella prima età del Rame in Sardegna: un approccio tecnologico, in L'età del Rame in Italia, Atti della XLIII Riunione Scientifica dell'Istituto Italiano di Preistoria e Protostoria, Bologna 26-29 novembre, Firenze : 551-556.

MANCA L. 2013. - Fonctionnement des sociétés de la fin du néolithique au début de l'àge du cuivre en Sardaigne. Une approche inédite à partir de l'étude des productions en matières dures animales. $\mathrm{PhD}$ Dissertation, Université d'Aix-Marseille, France, 764 p.

MANCA L. 2014. - The individuation of a new type of shell tools during Early Chalcolithic in Sardinia: the bevelled tools on oyster valves. An experimental approach to reconstruct the operational sequences, in Averbouh A., Margarit M. \& Le Dosseur G. (eds), Prehistoric Exploitation of Hard Animal Material. An Overview of the Exploitation of Hard Animal Materials during the Neolithic and Chalcolithic. Cetatea de Scaun, Targoviste: 153-180.

Mansur M. E. \& Clemente-Conte I. 2009. - ¿Tecnologías invisibles? Confección, uso y conservación de instrumentos de valva en Tierra del Fuego, in Oliva F., De Grandis N. \& Rodríguez J. (eds), Arqueología Argentina en los inicios de un nuevo siglo. Publicación del XIV Congreso Nacional de Arqueología Argentina II, Rosario, Argentina: 359-367.

Mansur M. E., Lima M. A. \& Maigrot Y. (eds) 2014. - Traceology today: methodological issues in the Old World and the Americas. Proceedings of the XVI World Congress of the International Union of Prehistoric and Protohistoric Sciences, Session XXXV, vol. 6. British Archaeological Reports International Series 2643, $96 \mathrm{p}$.

MÉDARD F. 2006. - Les Activités de Filage au Néolithique sur le Plateau Suisse. Analyse Technique, Économique et Sociale. CNRS Editions, Paris, 200 p. (Coll. CRA monographies; 28)

Melis M. G. 2011. — Considerazioni sull'età del rame nella sardegna centro-occidentale, in SPANU G. \& ZUCCA R. (eds) Oristano e il suo territorio. Dalla preistoria all'alto Medioevo Vol. 1. Carocci, Roma: 125-142.

PARSONS K.-M. \& BRETT C.-E. 1991. — Taphonomic processes and biases in modern marine environments: an actualistic perspective on fossil assemblage preservation, in DonOvan S. K. (ed.), The Processes of Fossilization. Belhaven Press, London: 22-65.

PasCUAL BENITO J. 2008. - Instrumentos neolíticos sobre soporte malacológico de las comarcas centrales valencianas, in HERNÁNDEZ Pérez M., Soler Díaz J. \& López Padilla J. (eds), IV Congreso del Neolitico Peninsular II. Diputatiòn Provincial de Alicante, Museo Arqueológico de Alicante: 290-297.

Peltier A. \& Plisson H. 1986. - Micro-tracéologie fonctionnelle sur l'os: quelques résultats expérimentaux, in PATOU MATHIS M. (ed.), Outillage peu élaboré en os et en bois de cervidés II. CEDARC, Treignes: 69-80. (Coll. Artefacts; 3).

PLISSON H. 1985. - Étude fonctionnelle d'outillages lithiques préhistoriques par l'analyse des micro-usures: recherche méthodologique et archéologique. PhD dissertation, Université de Paris I, 714 p.

PLISSON H. 2007. - Tracéologie fonctionnelle des matières osseuses : quelle méthode? Bulletin de la Société Préhistorique Française 104 (2): 377-380.

Plisson H. \& LOMPRÉ A. 2008. - Technician or researcher? A visual answer, in LONGO L. \& SKAKUn N. (eds), Prehistoric Technology 40 Years Later: Functional Studies and the Russian Legacy. British Archeological Reports International Series 1783: 503-508.

RAMPAZZi L., CARIaTI F., TANDA G. \& COlOMBINI M. P. 2002. Characterisation of wall paintings in the Sos Furrighesos necropolis (Anela, Italy). Journal of Cultural Heritage 3: 237-240. 
RODríGUEZ A. \& NAVARRO J. F. 1999. — La industria malacológica de la cueva de El Tendal (San Andrés y Sauces, isla de La Palma). Vegueta : anuario de la Facultad de Geografía e Historia 4: 75-100.

SanTONI V. 1977. - Cuccuru S’Arriu Cabras. Rivista Scienze Preistoriche 32 (1-2): 350-353.

SANTONI V. 1982a. - Il mondo del sacro in età neolitica. Le Scienze 170: 70-80.

SANTONI V. 1982b. - Cabras - Cuccuru S'Arriu. Nota preliminare di scavo (1978, 1979, 1980). Rivista di Studi fenici 1: 103-110.

SANTONI V. 1989. - Cuccuru S'Arriu - Cabras. Il sito di cultura San Michele di Ozieri. Dati preliminari, in CAmpus L. (ed.), La Cultura di Ozieri. Problematiche e nuove acquisizioni. Atti del I convegno di studio, gennaio 1986-aprile 1987, Il Torchietto, Ozieri: $169-200$.

SANTONI V. 1991. - Cabras-Cuccuru S'Arriu : l'orizzonte eneolitico sub-Ozieri. Quaderni della Soprintendenza archeologica per le province di Cagliari e Oristano 4 (1): 15-47.

SANTONI V. 1992. - Cuccuru S'Arriu (Cabras). L'orizzonte eneolitico sub-Ozieri, in Balmuth M. S., TyKOT R. H. \& ANDREWS T. K. (eds), Sardinia in the Mediterranean : a Footprint in the Sea. Sheffield Academic Press, Sheffield: 157-174. (Coll. Studies in Sardinian Archaeology).

Santoni V. 1999. — Le Néolithique Moyen-Supérieur de Cuccuru s'Arriu (Cabras-Oristano, Sardaigne), in : VAQUER J. (ed.), Le Néolithique Nord-Ouest méditerranéen, [colloque international organisé dans le cadre du] XXIVe congrès de la Société préhistorique française, Carcassonne, 26-30 septembre 1994. Mémoire de la Société Préhistorique Française 2: 77-87.

Santoni V., Bacco G. \& Sabatini D. 1997. — L'orizzonte Neolitico Superiore di Cuccuru s'Arriu di Cabras, Le sacche C.S.A. nn. 377, 380/1979 e n. 2/1989, in: CAMPUS L. (ed.), La cultura di Ozieri : la Sardegna e il Mediterraneo nel IV e III millennio a.C. Atti del II Convegno di studi, 15-17 ottobre 1990. Il Torchietto, Ozieri: 237-295.

Sebis S., Lugliè C. \& SAntoni V. 2012. - Il neolitico medio di Cuccuru is Arrius (Cabras, OR) nella struttura abitativa 422, in La Preistoria e la Protostoria della Sardegna, Atti della XLIV Riunione Scientifica dell'Istituto Italiano di Preistoria e Protostoria, Cagliari, Barumini, Sassari 23-28 Novembre 2009. Istituto Italiano di Preistoria e Protostoria, Firenze: 495-502.

SERRAND N. 2011. - Autres espaces, autres matériaux. Les «outils avec tranchant» en coquille des Petites Antilles précolombiennes: haches, herminettes, outils multifonctions?, in SERVELLE C. (ed.), Haches de pierre; au néolithique, les premiers paysans du Tarn. Comité départemental d'archéologie du Tarn, Castres: 601-610.

SERRAND N. \& Vigne J.-D. 2011. — La malacofaune et les crustacés : subsistance et matières premières, in GUILAINE J., BRIOIS F. \& VIGNE J.-D. (eds), Shillourokambos. Un établissement néolithique pré-céramique à Chypre. Les fouilles du Secteur 1. École Française d'Athènes; Errance, Paris: 807-833.

Spano C., Murgia D. \& Puddu B. 2002. - Malacofaune spiaggiate della costa occidentale della Sardegna. Fisiografia e batimetria dei fondali marini di provenienza. Rendiconti del Seminario della Facoltà di Scienze dell'Università di Cagliari 72 (2): 67-108.

STiglitz A. 1998. - Archeologia di un paesaggio: il Sinis (Sardegna centro-occidentale), in AA.VV., Associazione Culturale
Ossidiana (eds), La ceramica nel Sinis dal Neolitico ai giorni nostri, Atti del II Convegno di studi "La ceramica racconta la storia". Condaghes, Cagliari: 23-55.

SZABO K. 2008. - Shell as a raw material: mechanical properties and working techniques in the tropical Indo-West Pacific. Archaeofauna 17: 125-138.

SZABÓ K., BRUMm A. \& BellWoOd P. 2007. — Shell artefact production at 32 000-28 000 BP in Island Southeast Asia: thinking across media? Current Anthropology 48: 701-723. http://www. jstor.org/stable/10.1086/520131

SZABÓ K. \& Koppel B. 2015. - Limpet shells as unmodified tools in Pleistocene Southeast Asia: an experimental approach to assessing fracture and modification. Journal of Archaeological Science 54: 64-76. http://doi.org/10.1016/j.jas.2014.11.022

TABORIN Y. 2004. - Langage sans parole. La parure aux temps préhistoriques. La Maison des Roches, Paris, 216 p.

TAYLOR J.-D. \& LAYMAN M. 1972. - The mechanical properties of bivalve (mollusca) shell structures. Palaeontology 15 (1): 73-87.

Tumung L., Bazgir B., Ahmadi K. \& Shadmehr A. 2012. Understanding the use-wears on non-retouched shells Mytilus galloprovincialis and Ruditapes decussatus by performing wood working experiment: an experimental approach. International Conference on the Use of X-ray (and related) Techniques in Arts and Cultural Heritage (XTACH 11), 7-8 December 2011, Sharjah, United Arab Emirates. IOP Conference Series: Materials Science and Engineering 37 (1): 012017. http://doi.org/10.1088/1757$899 X / 37 / 1 / 012017$

Tumung L., Bazgir B. \& Ollé A. 2015. - Applying SEM to the study of use-wear on unmodified shell tools: an experimental approach. Journal of Archaeological Science 59: 179-196. http:// doi.org/10.1016/j.jas.2015.04.017

VAN GIJN A. \& LAMMERS-KEIJSERS Y. 2010. — Toolkits for ceramic production informal tools and the importance of high power use-wear analysis. Bulletin de la Société Préhistorique Française 107 (4): 755-762.

VIGIE B. 1987. — Essai d'étude méthodologique d'outils sur coquillages de la grotte de Camprafaud (Ferrières-Poussarou, Hérault). L'Anthropologie 91: 263-272.

VigiE B. 1995. - Du déchet alimentaire à l'objet coquillier: le statut des coquillages en milieu archéologique, in CAMPS G. (ed.), L'Homme préhistorique et la mer. Actes du $120^{e}$ Congrès national des Sociétés historiques et scientifiques. CTHS, Paris: 351-354.

Vigie B. \& COURTIN J. 1986. - Les outils sur coquilles marines dans le Néolithique du Midi de la France. Mesogée 46 (1): 51-61.

Vigie B. \& Courtin J. 1987. — Le problème des coquillages à bord dentelé dans la Préhistoire du midi de la France. Mesogée 47: 93-98.

ZANARDELLI T. 1899. - Le stazioni preistoriche e lacumarensi nel Campidano di Oristano. Bollettino di Paletnologia Italiana 25: 109-177.

Zilhāo J., Angelucci D. E., Badal-García E., D’Errico F., Daniel F., Dayet L., Douka K., Higham T. F. G., Martínez-SÁnCHEZ M.-J., Montes-Bernárdez R., Murcia-Mascarós S., PérezSirvent C., Roldán-García C., Vanhaeren M., Villaverde V., WOOD R. \& ZAPATA J. 2010. - Symbolic use of marine shells and mineral pigments by Iberian Neanderthals. Proceedings of the National Academy of Sciences of the USA 107 (3): 1023-1028. 